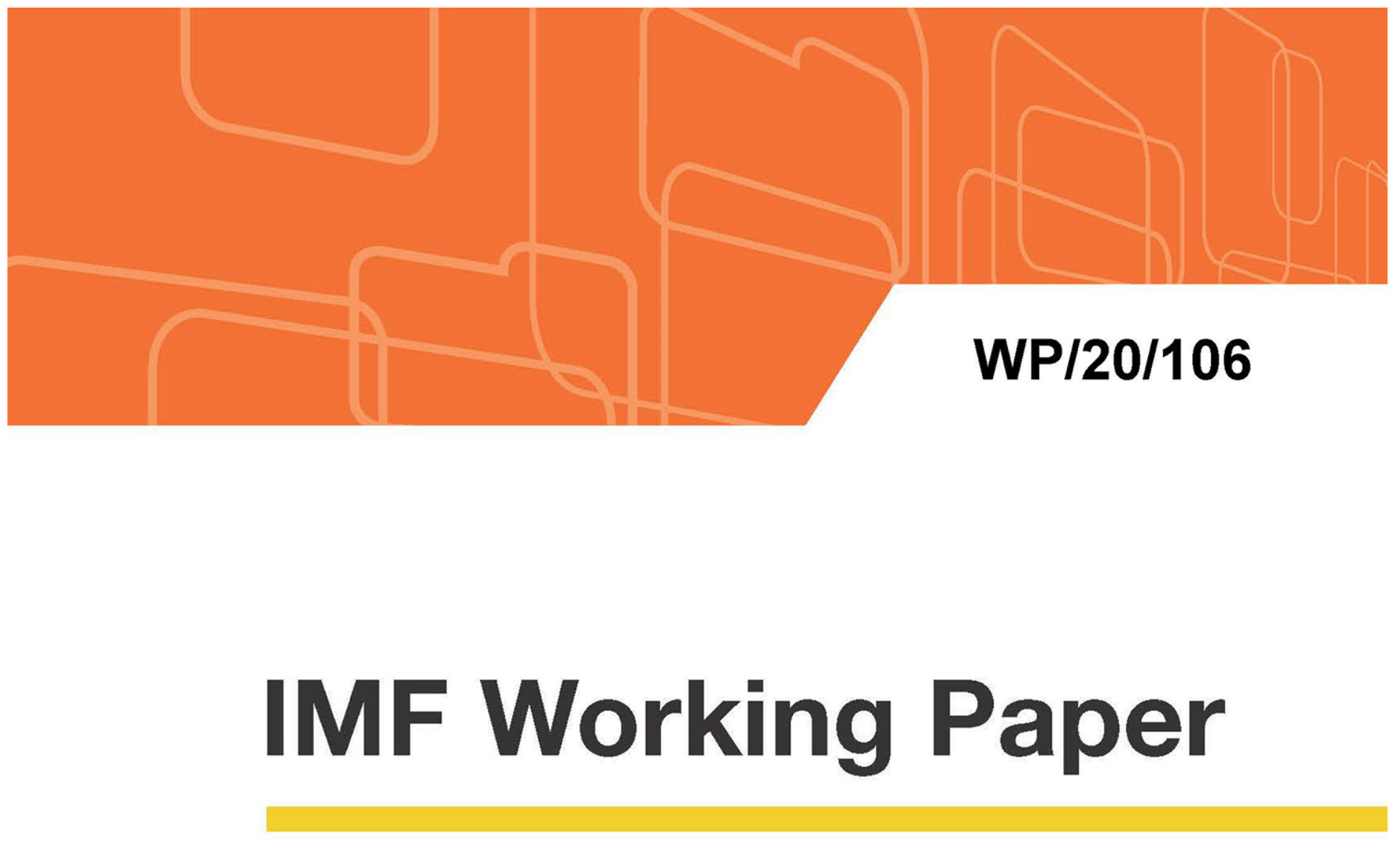

\title{
Dampening Global Financial Shocks: Can Macroprudential Regulation Help (More than Capital Controls)?
}

by Katharina Bergant, Francesco Grigoli, Niels-Jakob Hansen and Damiano Sandri

IMF Working Papers describe research in progress by the author(s) and are published to elicit comments and to encourage debate. The views expressed in IMF Working Papers are those of the author(s) and do not necessarily represent the views of the IMF, its Executive Board, or IMF management.

$$
\text { I N T E R N A T I O N A L M O N E T A R Y F U N D }
$$




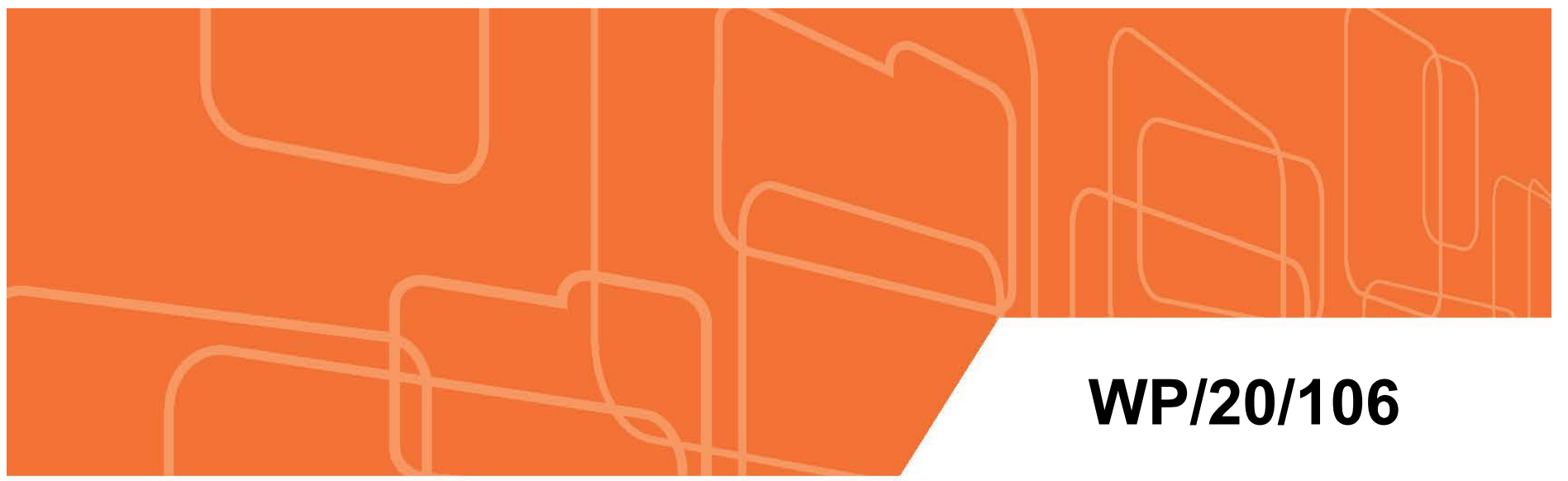

\section{IMF Working Paper}

\section{Dampening Global Financial Shocks: Can Macroprudential Regulation Help (More than Capital Controls)?}

by Katharina Bergant, Francesco Grigoli, Niels-Jakob Hansen and Damiano Sandri

IMF Working Papers describe research in progress by the author(s) and are published to elicit comments and to encourage debate. The views expressed in IMF Working Papers are those of the author(s) and do not necessarily represent the views of the IMF, its Executive Board, or IMF management. 


\title{
IMF Working Paper
}

Research Department

\section{Dampening Global Financial Shocks: Can Macroprudential Regulation Help (More than Capital Controls)?}

\section{Prepared by Katharina Bergant, Francesco Grigoli, Niels-Jakob Hansen and Damiano Sandri}

Authorized for distribution by Malhar Nabar

June 2020

IMF Working Papers describe research in progress by the author(s) and are published to elicit comments and to encourage debate. The views expressed in IMF Working Papers are those of the author(s) and do not necessarily represent the views of the IMF, its Executive Board, or IMF management.

\begin{abstract}
We show that macroprudential regulation can considerably dampen the impact of global financial shocks on emerging markets. More specifically, a tighter level of regulation reduces the sensitivity of GDP growth to VIX movements and capital flow shocks. A broad set of macroprudential tools contribute to this result, including measures targeting bank capital and liquidity, foreign currency mismatches, and risky forms of credit. We also find that tighter macroprudential regulation allows monetary policy to respond more countercyclically to global financial shocks. This could be an important channel through which macroprudential regulation enhances macroeconomic stability. These findings on the benefits of macroprudential regulation are particularly notable since we do not find evidence that stricter capital controls provide similar gains.
\end{abstract}

JEL Classification Numbers: F3, F4, E5

Keywords: Macroprudential policies, monetary policy, capital controls.

Author’s E-Mail Address: kbergant@imf.org, fgrigoli@imf.org, nhansen@imf.org, dsandri@imf.org 


\section{Introduction}

A growing literature documents that fluctuations in global financial markets can severely affect financial and macroeconomic conditions in emerging markets. ${ }^{1}$ When global financial conditions are buoyant, emerging markets tend to enjoy higher economic growth supported by abundant foreign capital inflows. Conversely, a tightening in global financial conditions - for example a sudden spike in global risk aversion as triggered by the COVID-19 pandemic - can considerably depress economic activity in emerging markets.

According to conventional macroeconomic theory, emerging markets should be able to offset the impact of global financial shocks by relying on exchange rate flexibility. Empirical evidence shows that a flexible exchange rate tends to soften the impact of foreign financial shocks on the domestic economy (Obstfeld et al., 2005). However, it falls short of providing full insulation. Global financial shocks can destabilize even emerging markets that have a flexible exchange rate, as documented in Rey (2015) and Rey (2016) among others. ${ }^{2}$ The vulnerability of emerging markets to global financial shocks leads to recurrent calls for policymakers to deploy additional policy tools. The discussion often centers on the role of capital controls and foreign exchange intervention as these tools directly target international financial transactions. However, there is growing awareness that macroprudential policies can also play an important role in stabilizing credit markets as discussed later in the literature review.

Against this background, the paper examines whether macroprudential regulation-which involves a broad range of measures to buttress financial stability - can dampen the macroeconomic impact of global financial shocks on emerging markets. The hypothesis underpinning the analysis is that by reinforcing balance sheets, preventing excessive risk taking, and limiting foreign currency exposures, macroprudential regulation strengthens the resilience of the domestic financial sector and thus enhances macroeconomic stability.

Ostry et al. (2012) provide early evidence in favor of this hypothesis, showing that countries with stronger macroprudential regulation were more resilient during the global financial crisis. Similarly, Neanidis (2019) finds that stronger bank supervision reduces the negative impact of volatile capital flows on economic growth. ${ }^{3}$

This paper examines the dampening effects of macroprudential regulation more systematically, using a broad set of global financial shocks and analyzing the experience of 38 emerging markets between 2000 and 2016. During this time, emerging markets were exposed to highly volatile global financial conditions, driven by large swings in US policy rates, global risk aversion — proxied by the VIX — and capital inflows, as illustrated in panels 1 and 2 of Figure $1 .{ }^{4}$ Global financial volatility significantly affected emerging markets. Panels 3 in Figure 1 show that GDP in emerging markets grew rapidly during the buoyant years before the global financial crisis and contracted sharply during it.

Meanwhile, emerging markets have gradually tightened macroprudential regulation. Panel 1 of Figure 2 shows the average number of macroprudential tightening actions per country in emerging markets using the IMF's integrated Macroprudential Policy (iMaPP) database compiled by Alam et al. (2019) . ${ }^{5}$ By cumulating

\footnotetext{
${ }^{1}$ See for example Canova (2005), Dedola et al. (2017), Maćkowiak (2007), Georgiadis (2016), Choi et al. (2017), Iacoviello and Navarro (2019), Bräuning and Ivashina (2020), and Vicondoa (2019).

${ }^{2}$ The theoretical literature finds that exchange rate flexibility becomes less effective in buffering external shocks in the presence of financial frictions (Ottonello, 2013; Farhi and Werning, 2016; Cavallino and Sandri, 2020; Akinci and Olmstead-Rumsey, 2018; Aoki et al., 2019) and trade invoicing in US dollars (Egorov and Mukhin, 2019; Gopinath et al., 2020).

${ }^{3}$ Brando-Marques et al. (2020) analyze the role of macroprudential policies in affecting the full distribution of future GDP growth. Focusing on the effectiveness of changes in macroprudential regulation, they find that these policies can dampen the downside risk to GDP growth arising from external financial shocks.

${ }^{4}$ Meanwhile, emerging markets' cross-border financial positions increased considerably as a share of GDP until the global financial crisis in 2008-09. They have remained broadly stable since then (Lane and Milesi-Ferretti, 2018).

${ }^{5}$ The iMaPP is the most comprehensive database on macroprudential policies available as of this writing. The database
} 
Figure 1: External and Domestic Conditions in Emerging Markets
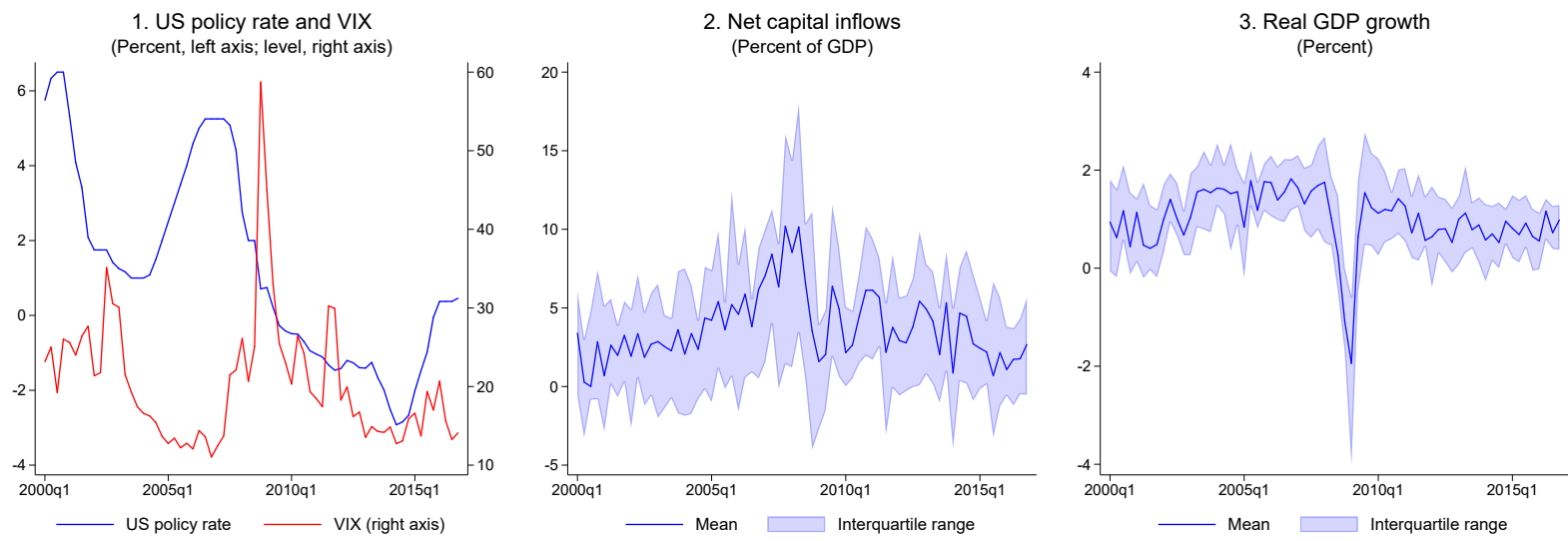

Source: Bank for International Settlements, IMF, International Financial Statistics database; Haver Analytics; Wu and Xia (2015); IMF, Balance of Payments; and authors' calculations.

Notes: The US policy rate is the federal funds rate except during the zero lower bound (ZLB) period where we use the implied rate from $\mathrm{Wu}$ and Xia (2015).

the tightening actions (net of the loosening ones) for each country since 1990, we construct an approximate measure of the stringency of macroprudential regulation. Panel 2 of Figure 2 shows that macroprudential regulation has been considerably tightened over the years, especially since 2005 . The global financial crisis led to a temporary loosening but emerging markets returned to tighten regulation during the subsequent recovery. Panel 2 also illustrates a substantial dispersion in the level of macroprudential regulation across countries.

Figure 2: Macroprudential Policy
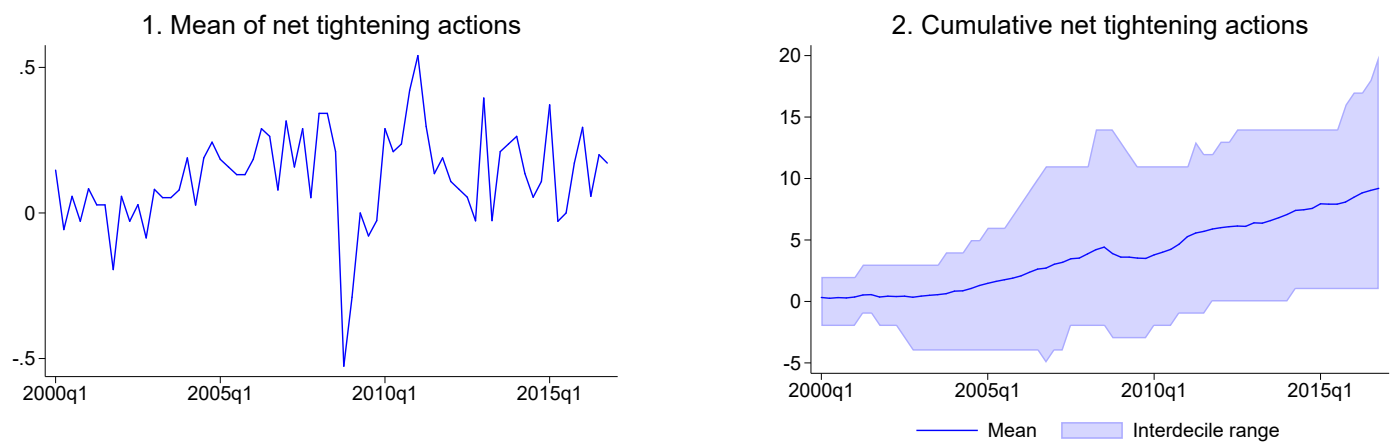

Source: IMF, integrated Macroprudential Policy (iMaPP) Database; and authors' calculations.

Notes: Panel 1 shows the cross-country average of net tightening actions; panel 2 shows the cross-country average of the cumulative net tightening actions. The shaded area in panel 2 corresponds to the interdecile range.

By exploiting both time-series and cross-country variation in macroprudential regulation, we first show that a more stringent level of regulation significantly reduces the sensitivity of GDP growth in emerging markets to global financial shocks. These results are robust to a broad set of endogeneity tests, alleviating concerns about reverse causality and omitted variables.

records tightening and loosening actions for a broad set of macroprudential tools between 1990 and 2016. These include measures that aim to boost bank capital and liquidity, limit foreign exchange mismatches, and prevent risky lending to leveraged borrowers. 
We also find that the dampening effects of macroprudential regulation display decreasing marginal returns. At more stringent levels of macroprudential regulation, further macroprudential tightening becomes less effective in strengthening resilience. This is consistent with concerns about circumvention, whereby excessive macroprudential regulation may push financial activities outside the regulatory perimeter and increase cross-border borrowing. ${ }^{6}$

The dampening effects of macroprudential regulation are not driven by a particular set of tools. A broad range of macroprudential measures contribute to enhancing macroeconomic resilience to global financial shocks. These include macroprudential tools that boost bank capital and liquidity, limit foreign exchange exposures, and avert overly risky forms of credit. However, the dampening properties of these tools are heterogeneous and depend on the type of global financial shock hitting the economy. We also document that macroprudential regulation leads to symmetric dampening effects against positive and negative global financial shocks. A higher level of macroprudential regulation supports GDP growth when global financial shocks are adverse but it lowers economic activity when global financial conditions are favorable.

We also analyze if macroprudential regulation may entail negative spillovers. If a country shields itself using macroprudential regulation against global financial volatility, other countries may end up getting more exposed. However, we do not find evidence of such negative spillovers. Rather, we find that a higher level of macroprudential regulation in one country tends to enhance macroeconomic stability in other countries. This suggests that macroprudential regulation reduces the propagation of global financial shocks, possibly because enhanced resilience in a given country leads to more stable cross-border trade and financial flows.

After documenting the dampening properties of macroprudential regulation on economic activity, we investigate if macroprudential regulation allows for a more countercyclical response of monetary policy to global financial shocks. This could be an important channel through which macroprudential regulation may enhance macroeconomic stability. Central banks in emerging markets are generally reluctant to cut policy rates when global financial conditions tighten even after controlling for expected inflation (Obstfeld et al., 2005; Aizenman et al., 2016; Aizenman et al., 2017; Han and Wei, 2018; Cavallino and Sandri, 2020; Bhattarai et al., 2020). This is likely because they fear that a sharp exchange rate depreciation or large capital outflows may jeopardize financial stability. By strengthening balance sheets and limiting risk taking, macroprudential regulation should alleviate these concerns and help monetary policy to focus more squarely on macroeconomic stabilization. We find that macroprudential regulation indeed allows for a more countercyclical monetary policy response. At low levels of macroprudential regulation central banks tend to respond procyclically, by increasing rates when global financial conditions tighten. But at more stringent levels of regulation, the monetary policy response becomes countercyclical, involving a decline in policy rates when global financial conditions tighten.

Finally, to put in perspective the benefits from macroprudential regulation uncovered by the analysis, we ask how they compare to those from capital controls. The existing literature generally considers capital controls as the key policy tool beyond exchange rate flexibility to protect emerging markets from global financial shocks. This view originates from the Mundell-Fleming trilemma whereby restrictions on capital flows are expected to provide countries with greater control over domestic financial and macroeconomic conditions, thus strengthening resilience to external shocks. Following the same empirical approach used to analyze macroprudential regulation, we ask whether more stringent capital controls can also dampen global

\footnotetext{
${ }^{6}$ See for example Ongena et al. (2013), Aiyar et al. (2014), Reinhardt and Sowerbutts (2015), Cerutti et al. (2017), Ahnert et al. (2018), Bengui and Bianchi (2018), Braggion et al. (2018), Auer and Ongena (2019), Cizel et al. (2019), and Acharya et al. (2020).
} 
financial shocks and support a more countercyclical response of monetary policy. Using a broad set of capital control indicators provided by Chinn and Ito (2008), Fernández et al. (2015), Quinn and Toyoda (2008), and Pasricha et al. (2018), we do not find evidence that tighter capital controls provide similar benefits to those of tighter macroprudential regulation. These findings are in line with those presented in Forbes et al. (2015) and Frost et al. (2020). Using propensity score matching procedures, these studies find that macroprudential tools, especially FX-based measures, are more effective in influencing macroeconomic outcomes than capital controls.

The results of the analysis are subject to two main caveats. First, as later discussed in more detail, indexes of macroprudential regulation are still subject to significant measurement limitations. Therefore, our findings will need to be re-evaluated as better measures become available. Second, although the results are robust to a broad range of tests that exploit both time-series and cross-section identification and control for various variables, some endogeneity concerns may linger. In particular, we cannot rule out that the results could be biased by a variable that has been omitted from the empirical specifications, beyond the various ones considered in the robustness tests. To create a bias, this variable should comove over time and across countries with macroprudential regulation and it should affect macroeconomic resilience. Measurement limitations and omitted variable concerns also apply to the analysis of capital controls.

Literature review Our results relate to a growing literature on the effectiveness of macroprudential policies in controlling domestic credit and house prices. Various papers use country-level panel data as in our analysis. Cerutti et al. (2017) find that borrower-based and financial macroprudential tools affect credit growth in emerging markets. Similarly, Fendoğlu (2017) and Akinci and Olmstead-Rumsey (2018) document that macroprudential policies can curb credit and house price growth. Several other papers confirm that macroprudential policies can stabilize real house prices (Crowe et al., 2013; Cerutti et al., 2015; Kuttner and Shim, 2016; Wong et al., 2011). Looking at credit cycles, Dell'Ariccia et al. (2012) show that macroprudential policies can reduce the frequency of credit booms and decrease the severity of subsequent busts. Focusing on bank balance sheets, Claessens et al. (2013) find that macroprudential measures based on credit limits are effective in controlling leverage.

Micro-level studies confirm the effectiveness of macroprudential policies in affecting credit growth. Using data from Spain, Saurina (2009) and Jiménez et al. (2017) find that dynamic provisioning can mitigate credit booms and busts. Aiyar et al. (2016) and Dassatti et al. (2019) use bank-level data for Uruguay and the UK, respectively, and show that reserve and capital requirements have significant effects on credit. Igan and Kang (2011) and Tillmann (2015) use sectoral data from Korea to show that limits to loan-to-value and debt-to-income ratios moderate credit growth.

In addition to financial variables, a few papers have analyzed the effects of macroprudential regulation on GDP growth. Some papers find that a tightening in macroprudential policies leads to a temporary decline in GDP (Kim and Mehrotra, 2018; Eickmeier et al., 2018; Richter et al., 2019). Other papers focus on longer-term effects, finding that macroprudential policies tend to boost average economic growth (Boar et al., 2017; Agénor et al., 2018; Neanidis, 2019).

Our paper differs from the literature because we do not analyze the impact of changes in macroprudential regulation on domestic conditions. We instead examine if the level of macroprudential regulation - and later the stringency of capital controls - affects the transmission of global financial shocks to the domestic economy. Besides providing a different perspective on the effects of macroprudential regulation, this research question 
is subject to much less severe endogeneity concerns. While changes in regulation are likely triggered by economic developments that complicate identification, the level of regulation when global financial shocks materialize is largely pre-determined being the outcome of easing and tightening decision over the previous years. Furthermore, the robustness of the results can be validated using cross-sectional identification by examining whether countries that have on average tighter macroprudential regulation over a certain period tend to be less destabilized by global financial shocks. This approach neglects any time-series variation in macroprudential regulation, thus further addressing concerns about reverse causality.

The rest of paper is structured as follows. Section 2 analyzes if macroprudential regulation can dampen the effects of global financial shocks in emerging markets. Section 3 considers whether macroprudential regulation allows for a more countercyclical monetary policy response. Section 4 examines if capital controls are as effective as macroprudential regulation in dealing with global financial shocks. Section 5 concludes by summarizing the key insights of the paper and discussing avenues for future research.

\section{Dampening effects of macroprudential regulation}

Macroprudential regulation involves a broad set of policy tools that aim to contain the build up of systemic vulnerabilities and strengthen the resilience of the financial sector. These include measures to increase bank capital and liquidity, reduce leverage in the household and corporate sectors, and prevent currency mismatches. The hypothesis motivating the analysis in this paper is that, by buttressing financial sector stability, macroprudential regulation should also enhance macroeconomic resilience to global financial shocks. Does the empirical evidence support this logic?

To address this question, we estimate panel regressions of GDP growth in emerging markets over a vector of global financial shocks and their interactions with the stringency of macroprudential regulation. ${ }^{7}$ The coefficient estimates on the interaction terms indicate if the impact of global financial shocks on emerging markets' GDP is affected by the level of macroprudential regulation.

More precisely, the analysis is based on the following panel regression:

$$
Y_{i, t}=\alpha_{i}+\beta S_{i, t}+\gamma\left(S_{i, t} \cdot M \operatorname{Pru} u_{i, t}\right)+\delta\left(S_{i, t} \cdot M \operatorname{Pru} u_{i, t}^{2}\right)+\zeta M P r u_{i, t}+\theta M P r u_{i, t}^{2}+\kappa C_{i, t}+\varepsilon_{i, t}
$$

where $Y_{i, t}$ denotes quarterly real GDP growth for country $i$ at time $t$ and $\alpha_{i}$ is a country fixed effect for country $i$. The variable $S_{i, t}$ denotes the vector of global financial shocks and $M P r u_{i, t}$ is the level of macroprudential regulation. To allow for non-linear effects, the specification includes interaction terms of the shocks with the squared level of macroprudential regulation. Note that the coefficients on the interactions between the shocks and macroprudential regulation are estimated by exploiting both time-series and crosscountry variation in the data. They indeed capture both if the impact of the shocks becomes less severe in a given country if the level of macroprudential regulation tightens over time; and if the impact of the shocks is less severe in countries that have a tighter level of macroprudential regulation.

The regression specification (1) includes a vector of control variables $C_{i, t}$ that, following Obstfeld et al. (2019), features lagged GDP growth, lagged log of real GDP per capita, institutional quality, and a linear trend. Furthermore, the vector $C_{i, t}$ includes the lagged output gap to control for growth dynamics over the

\footnotetext{
7This approach is inspired by Obstfeld et al. (2019) who analyze if the impact of the VIX on emerging markets' macroeconomic conditions is influenced by the exchange rate regime.
} 
business cycle and commodity terms of trade since several emerging markets are large importers or exporters of commodities. ${ }^{8}$ We exclude time fixed effects since they would prevent us from estimating the impact of common global financial shocks on GDP and thus assess the quantitative importance of the dampening effects of macroprudential regulation. We will include time fixed effects in the robustness section, showing that the results are unchanged.

The vector $S_{i, t}$ includes three types of global financial shocks. First, we consider shocks to US monetary policy to capture changes in the international risk-free rate. We use the shocks identified by Iacoviello and Navarro (2019) that have been shown to have tangible effects on emerging markets. ${ }^{9}$ Second, we include the Chicago Board Options Exchange's Volatility Index (VIX), which is commonly used in the literature as a proxy for shocks to international risk premia. Finally, the vector $S_{i, t}$ includes net capital inflows to capture shocks to the supply of foreign capital. ${ }^{10}$ Since net capital flows are also affected by domestic pull factors, we isolate the variation due to global push factors by instrumenting net capital inflows to country $i$ with gross inflows to the other emerging markets following Blanchard et al. (2017). The idea is that the total amount of foreign capital flowing to emerging markets, except the country in question, captures the general appetite of international investors for emerging markets' assets.

Most papers in the literature analyze only one of these three shocks. Our empirical framework includes all of them to capture all major sources of global financial shocks and understand which of them is more detrimental to emerging markets. Furthermore, the analysis can examine if macroprudential regulation enhances macroeconomic resilience against a broad set of shocks or only particular types. We will report the regression results throughout the paper by inverting the sign of net capital inflows, thus considering the effects of net capital outflows. In this way, all three shocks (to US rates, VIX, and net outflows) are expected to have a negative impact on emerging markets.

We construct the index of macroprudential regulation $M P r u_{i, t}$ by cumulating the macroprudential tightening actions net of the loosening actions reported in the iMaPP database from 1990 (the first year in the iMaPP database) to 2016 (the last year at the time of this work). ${ }^{11}$ A similar approach has been used by Akinci and Olmstead-Rumsey (2018) to analyze how the stance in macroprudential regulation affects credit growth. This index is subject to two measurement drawbacks which reflect the limitations of existing macroprudential data. First, countries may have had a different level of macroprudential regulation in 1990, thus confounding cross-country rankings. Second, the dummy-type policy action indicators of the iMaPP database record when macroprudential regulation was tightened and loosened but not the intensity of those changes. ${ }^{12}$

These measurement problems could affect the accuracy of our regression estimates but are unlikely to drive our results on the dampening effects of macroprudential regulation. As discussed for example in Akinci and Olmstead-Rumsey (2018) and Forbes (2018), measurement imprecision should bias the analysis against finding significant effects associated with macroprudential regulation rather than generate spurious evidence

\footnotetext{
${ }^{8}$ Compared to Obstfeld et al. (2019), the regression does not control for the contemporaneous credit to GDP ratio since a possible channel through which global financial shocks affect GDP growth (the left-hand side variable) is through the impact on domestic credit.

${ }^{9}$ These are computed as the residuals from a regression of the federal funds rate on US inflation, US log GDP, US corporate spreads, and the log of foreign GDP. Iacoviello and Navarro (2019) provide a time-series of the shocks until 2016:Q2 which we extended until 2016:Q4.

${ }^{10}$ Throughout the paper, we normalize capital flows by the HP-trend of GDP. We use the HP-trend rather than actual GDP to avoid introducing volatility driven by short-term fluctuations in the denominator.

${ }^{11}$ Since the index enters quadratically in the regression specification, we re-scale the index upward across all countries to ensure that values are always positive.

${ }^{12}$ The iMaPP database provides an indicator of policy intensity only for the LTV limits.
} 
about their benefits. To mitigate concerns about measurement problems, we will show that the results are robust to using both time-series and cross-sectional variation in the data.

The estimation approach uses a two-stage least squares procedure, where net capital inflows to country $i$ (as well as their interaction with macroprudential regulation and with macroprudential regulation squared) are instrumented with gross capital inflows to all other emerging markets (and their interactions). Given the complex correlation structure of the error term involving dependence across economies, autocorrelation, and heteroscedasticity, we apply the Driscoll and Kraay (1998) correction to the standard errors to make statistical inference. ${ }^{13}$

\subsection{Baseline results}

Table 1 reports the regression results. We start in column (1) by analyzing the impact of global financial shocks on emerging markets' GDP growth without controlling for the level of macroprudential regulation. An increase in the VIX and an outflow of capital have negative and highly statistically significant effects on economic growth. US monetary shocks have a detrimental effects on growth if the regression does not control for other global financial shocks, as shown in column (2). But they lose significance when controlling for the VIX and capital flows. Interestingly, this suggests that changes in US monetary policy affect emerging markets through changes in risk premia proxied by the VIX and the effects on the supply of foreign capital, rather than through changes in risk-free rates. Similar arguments are developed in Kalemli-Özcan (2019), who shows that US monetary policy transmits globally through changes in risk premia. Regarding the control variables, the coefficient on the lag of the output gap turns out to be negative and significant, suggesting that deviations from potential growth tend to be reduced over the following quarter. The instrumentation approach for net capital flows appears reliable since the $F$-statistic is well above the conventional threshold. ${ }^{14}$

The level of macroprudential regulation and its interactions with global financial shocks enter the regression specification in column (3). The coefficients on the VIX and net outflows remain significant. Importantly, the coefficients on the interaction terms between the shocks and macroprudential regulation are negative and highly statistically significant. This implies that a more stringent level of macroprudential regulation dampens the effects of global financial shocks on GDP growth. Column (4) shows that the results are robust to excluding periods during which countries had a fixed exchange rate.

Column (5) extends the regression specification to include the squared level of macroprudential regulation and its interactions with the shocks. The results corroborate the contractionary effects of VIX increases and capital outflows as well as the dampening effects of macroprudential regulation. Moreover, the interaction terms of the VIX and capital flows with the squared level of regulation are negative and statistically significant. The dampening effects of macroprudential regulation are thus subject to decreasing marginal returns, thereby weakening as the level of regulation tightens.

To better understand the dampening effects of macroprudential regulation, it is helpful to analyze the derivative of GDP growth with respect to a given global financial shock $j$. Based on equation (1), the

\footnotetext{
${ }^{13}$ Lagrange Multiplier tests point to the existence of serial correlation and the modified Wald test for group-wise heteroskedasticity indicates the presence of heteroscedasticity. Also, the Pesaran test, the Frees test, and the Friedman test all reject the null hypothesis of cross-sectional independence.

${ }^{14}$ In the regression results, we report the Kleibergen-Paap rk Wald $F$-statistic, which assumes non-iid errors and is appropriate with more than one endogenous regressors.
} 
derivative is equal to:

$$
\frac{\partial Y_{i, t}}{\partial S_{j, t}}=\beta+\gamma_{j} M \operatorname{Pru}_{i, t}+\delta_{j} M \operatorname{Pru}_{i, t}^{2}
$$

which is a nonlinear function of the level of macroprudential regulation. The first two panels in Figure 3 illustrate the derivatives with respect to the VIX and capital flow shocks. More specifically, the charts show the impact of these shocks on GDP in emerging markets as a function of the stringency of macroprudential regulation on the horizontal axis. The third panel in Figure 3 shows the distribution of macroprudential regulation in emerging markets in the regression sample (between 2000-2016) and at the end of 2016.

Figure 3: GDP Response in Emerging Markets to Global Financial Shocks
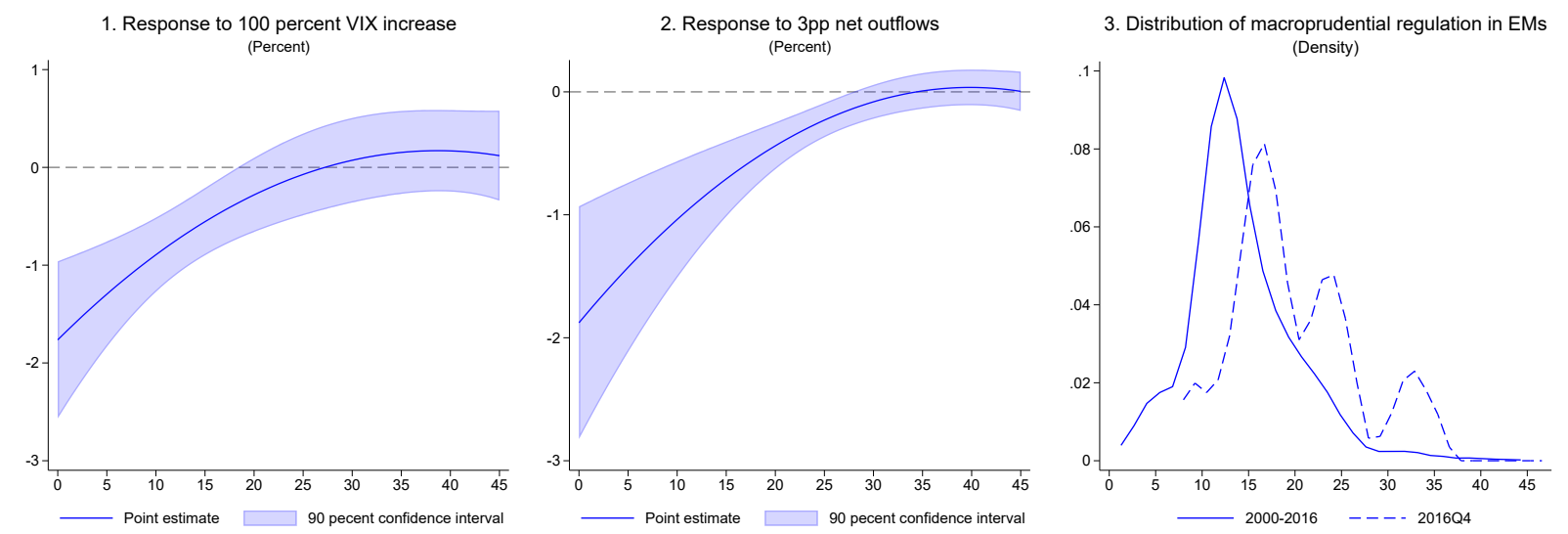

Source: Authors' calculations.

Notes: The x-axis denotes the level of macroprudential regulation. Panels 1 and 2 show the GDP response to global financial shocks for different levels of macroprudential regulation; panel 3 shows the probability density function of macroprudential regulation in the sample. Net capital outflows are scaled by the HP-trend of GDP. The shaded areas correspond to 90 percent confidence intervals computed with Driscoll-Kraay standard errors.

At the lowest level of macroprudential regulation in the sample, an increase in the VIX or an outflow of capital considerably reduce economic growth in emerging markets. For example, a doubling of the VIX - an increase similar to the one occurred during the global financial crisis-leads to a decline in quarterly GDP growth by 1.8 percentage points. Similar effects are triggered by a net outflow worth three percent of GDP. Macroprudential regulation can considerably dampen these effects. When faced with the same shocks, a country with a median level of macroprudential regulation in the sample would experience a GDP decline of only 0.5 percentage points. In fact, if the level of macroprudential regulation is sufficiently tight, the VIX and net capital outflows no longer have statistically significant effects on emerging markets' GDP.

The first two charts in Figure 3 illustrate also that the dampening effects of macroprudential regulation face decreasing marginal returns. A tightening in macroprudential regulation becomes progressively less effective in strengthening resilience to global financial shocks. These non-linearities are possibly consistent with problems of circumvention. As the stringency of regulation increases, domestic borrowers have stronger incentives to seek credit in the unregulated shadow financial market or from international lenders. ${ }^{15}$ These forms of credit are likely to be more sensitive to global financial conditions and thus could weaken the dampening effects of macroprudential regulation.

\footnotetext{
${ }^{15}$ See the literature cited in the introduction.
} 


\subsection{Robustness}

A possible concern about the analysis is that the level of macroprudential regulation may respond to changes in GDP growth, in which case the results would be confounded by reverse causality. In this regard, it is reassuring that the level of macroprudential regulation is quite persistent and much less volatile than quarterly fluctuations in GDP growth. In fact, since the level of macroprudential regulation is obtained by cumulating all past tightening and loosening macroprudential actions, it is largely predetermined to the realization of global financial shocks and their GDP responses. Besides, macroprudential policies are generally not adjusted in reference to growth developments as documented in Richter et al. (2019) for the case of loan-to-value ratios. ${ }^{16}$

Nonetheless, in Table 2 we perform various robustness tests for reverse causality. As policymakers might be more prone to change macroprudential regulation in bad times, the first test excludes all observations with negative GDP growth (column 1). We then check if the results are robust to lagging the level of macroprudential regulation by one quarter (column 2) and one year (column 3). Finally, to rule out reverse causality concerns, we replace the time-varying levels of macroprudential regulation with time-invariant country averages between 2000 - 2016 period (column 4). In this specification, the dampening effects of macroprudential regulation are identified by exclusively relying on cross-country heterogeneity in the stringency of macroprudential regulation. In other words, we ask if countries that on average have a more stringent level of macroprudential regulation are less affected by global financial shocks.

Across all these specifications, the coefficients on the interaction terms between macroprudential regulation and the VIX or net outflows remain positive and highly statistically significant. Therefore, the dampening effects of macroprudential regulation appear robust to reverse causality.

A second concern about the analysis is that the results could be affected by omitted variable bias. The dampening effects attributed to macroprudential regulation could be driven by country characteristics or policy actions that are correlated with macroprudential regulation and have been omitted from the analysis. To address these concerns, the regression specification is augmented with interaction terms between the global financial shocks and various factors that may affect resilience.

These factors include country structural characteristics such as institutional quality and financial development; ${ }^{17}$ fiscal variables such as gross public debt in percent of GDP, gross public debt in foreign currency in percent of total public debt, and the cyclically-adjusted fiscal balance in percent of GDP; and monetary policy variables such as the monetary policy rate and the anchoring of inflation expectations (Bems et al., 2018). We also control for the exchange rate regime, distinguishing between fixed and floating exchange rates (Ilzetzki et al., 2019); for the stringency of capital controls (Fernández et al., 2016); and for the stock of official reserves in percent of GDP. Table 3 shows the dampening effects of macroprudential regulation are robust to all the omitted variable tests. ${ }^{18}$

Column (11) in Table 3 shows that the results are also robust to the inclusion of time fixed effects, which

\footnotetext{
${ }^{16}$ Using a narrative approach, Richter et al. (2019) find that, out of 92 changes in loan-to-value ratios in a sample of 56 economies during 1990 and 2012, only three were motivated in reference to developments in GDP, inflation, or other real variables.

${ }^{17}$ We use the IMF's Financial Development Index that measures the development of financial institutions and financial markets in terms of depth, access, and efficiency.

${ }^{18}$ In these tests, the instrumentation becomes cumbersome, since three variables need to be instrumented: net outflows, their interaction with the level of macroprudential regulation, and their interaction with relevant variable for the test. As shown in Table 3, the $F$-statistic falls below ten when institutional quality, public debt, and the inflation expectation anchoring index are used.
} 
capture all factors common to the countries in our sample. In this specification, we can no longer estimate the impact of US monetary shocks and the VIX since these shocks are also common to all countries. However, we can still estimate the interaction terms of the global financial shocks with the level of macroprudential regulation. The interactions with the VIX and capital outflows remain positive and statistically significant, thus confirming the dampening effects of macroprudential regulation. Finally, we also verified that the results are robust to excluding any country from the sample and to dropping the period of the global financial crisis. ${ }^{19}$

\subsection{Symmetric dampening effects}

The previous analysis established that macroprudential regulation reduces the sensitivity of GDP growth in emerging markets to VIX and capital outflow shocks. Are these dampening effects at play against both positive and negative shocks? To address this question, we extend the regression specification to include dummies that differentiate between an increase or decrease in the global financial shocks:

$$
\begin{aligned}
Y_{i, t}= & \alpha_{i}+\beta^{+} D_{i, t}^{+} s_{i, t}^{n}+\beta^{-} D_{i, t}^{-} s_{i, t}^{n}+\gamma^{+} D_{i, t}^{+} s_{i, t}^{n} M \operatorname{Pru}_{i, t}+\gamma^{-} D_{i, t}^{-} s_{i, t}^{n} M \operatorname{Pru}_{i, t} \\
& +\zeta^{+} D_{i, t}^{+} \operatorname{MPru}_{i, t}+\zeta^{-} D_{i, t}^{-} \operatorname{MPr}_{i, t}+\beta^{\not h} S_{i, t}^{\not h}+\gamma^{\not h} S_{i, t}^{\not h} \operatorname{Mru}_{i, t}+\kappa C_{i, t}+\varepsilon_{i, t}
\end{aligned}
$$

where $s_{i, t}^{n} \in S_{i, t}$ is a specific global shock, $D_{i, t}^{+}\left(D_{i, t}^{-}\right)$is a dummy variable that takes value one when shock $s_{i, t}^{n}$ is positive (negative), and zero otherwise. The coefficients $\gamma^{+}$and $\gamma^{-}$measure the dampening effects of macroprudential regulation under a positive and negative shock realization, respectively. The vector $S_{i, t}^{\not h}$ includes the global financial shocks other than $s_{i, t}^{n}$.

Table 4 shows that the $\gamma^{+}$and $\gamma^{-}$coefficients for both the VIX (column 1) and capital outflows (column 2) are statistically significant and positive. Furthermore, the coefficients are quite similar in size, and a Wald test confirms that they are not statistically different. Therefore, macroprudential regulation entails symmetric dampening effects against both positive and negative global financial shocks. This implies that, while a tighter level of macroprudential regulation supports economic growth in case of negative financial shocks, it also lowers economic activity when global financial shocks are positive.

Figure 4 provides an illustration of the dampening effects of macroprudential regulation against positive and negative shocks. ${ }^{20}$ It shows the GDP growth rate differential between a country with high and low level of macroprudential regulation over the sample period 2000-2016. These levels are based on the 75th and 25th percentiles of the distribution of macroprudential regulation in the sample of analysis.

Higher regulation would have delivered significantly stronger economic growth in the early 2000s and during the global financial crisis, when global financial conditions were adverse. For example, higher macroprudential regulation would have increased quarterly GDP growth by about 0.6 percent between the fourth quarter of 2008 and the second quarter of 2009. However, macroprudential regulation would have lowered economic growth considerably in the years before the global financial crises, when global financial conditions were buoyant. By doing so, macroprudential regulation reduces the amplitude of economic fluctuations by sustaining growth in the face of adverse shocks while lowering economic activity when global financial conditions are supportive.

Maintaining a high level of macroprudential regulation to dampen negative financial shocks is thus not

\footnotetext{
${ }^{19}$ Results are available upon request.

${ }^{20}$ The chart is based on the coefficients in column (5) of Table 1, which includes quadratic terms in the level of regulation to capture non-linearities.
} 
Figure 4: Growth Differential between High/Low Macroprudential Regulation

(Percent)

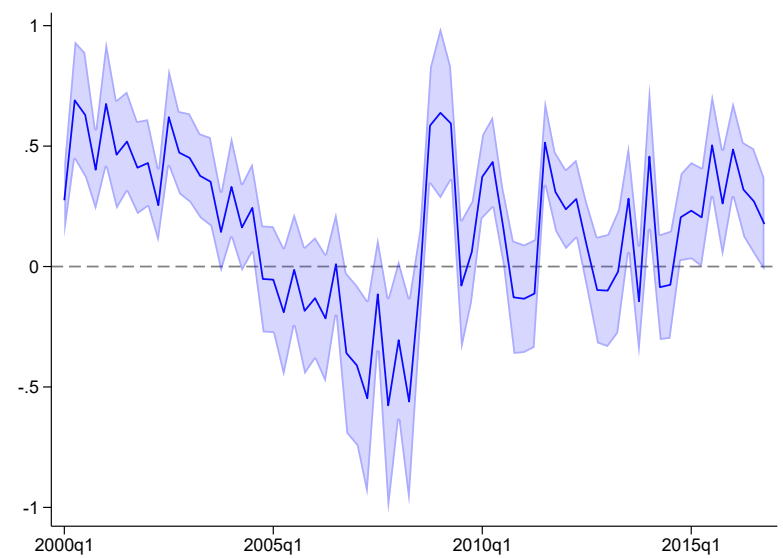

Source: Authors' calculations.

Notes: The blue line displays the growth differential between a country with macroprudential regulation set at the 75 th percentile of the sample distribution and a country with macroprudential regulation set at the 25th percentile of the sample distribution. The shaded area correspond to the 90 percent confidence interval computed with Driscoll-Kraay standard errors.

costless since it implies foregoing growth opportunities when global financial conditions are favorable. At the same time, it would be improper for policymarkers to tighten regulation only when global financial conditions become adverse. Constraining excessive risk-taking and credit provision when financial conditions are loosethus limiting economic activity - is a key channel through which macroprudential regulation ensures greater resilience at times of financial distress. These considerations call for further analysis on how to optimally adjust macroprudential regulation to maximize the dampening effects against negative shocks without unduly constraining economic activity when financial conditions are supportive.

\subsection{Categories of macroprudential measures}

Up to this point, we have used an overall index of macroprudential regulation that combines a broad range of individual measures recorded in the iMaPP database. We now examine if the dampening effects of macroprudential regulation are driven by specific measures. To investigate this issue, we replicate the analysis using more disaggregated categories of macroprudential regulation, including measures targeted at bank capital and liquidity, credit demand (such as loan-to-value ratios), credit supply (such as limits on credit growth), and foreign currency exposure. ${ }^{21}$

Table 5 analyzes the dampening effects of each macroprudential category. Figure 5 displays the results, reporting the coefficient estimates on the interaction terms of each macroprudential category with the VIX (panel 1) and net capital outflows (panel 2). Positive and statistically significant coefficients denote dampening effects. Measures targeted at credit demand, FX exposure, and liquidity dampen the impact on GDP growth arising from the VIX. Macroprudential measures targeted at bank capital, credit demand, and credit supply strengthen resilience against net capital outflows.

\footnotetext{
${ }^{21}$ Table A.3 in Appendix A describes the mapping from individual tools in the iMaPP to these broader categories. The analysis cannot be run on individual macroprudential tools because of the sparsity of the data.
} 
Figure 5: Dampening Effects on GDP Growth by Categories of Macroprudential Measures (Percent)
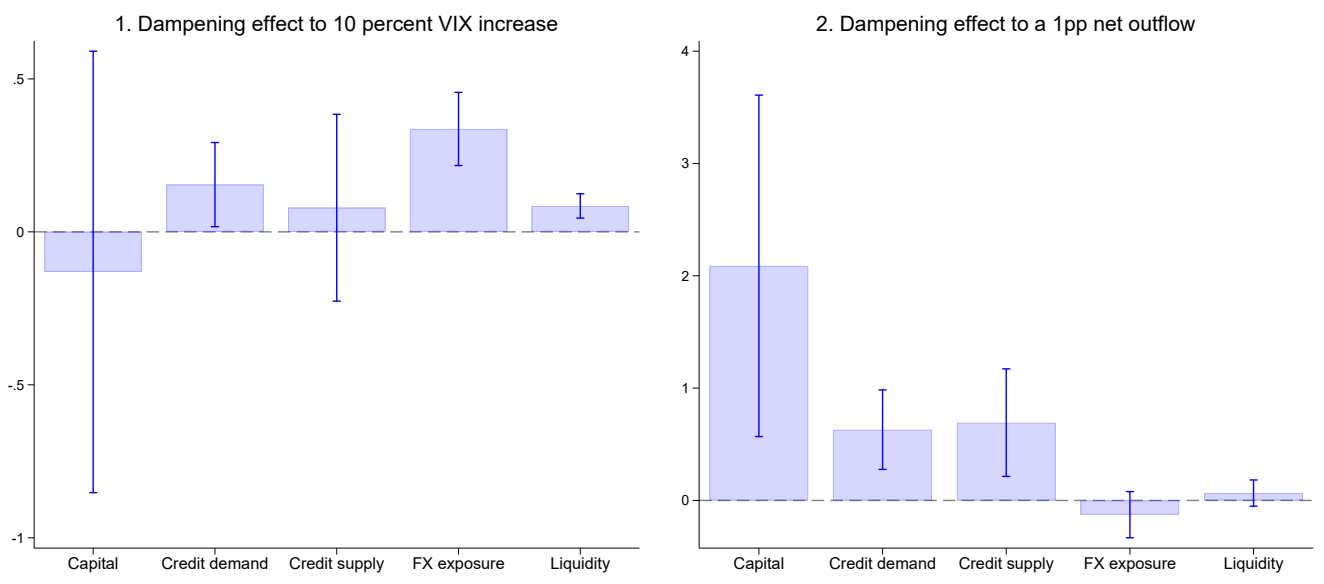

Source: Authors' calculations.

Notes: The bars in panels 1 and 2 show the point estimate of the coefficient on the interaction term between the shock and the level of macroprudential regulation. The level of macroprudential regulation is divided by 10 to ease the visualization of the coefficients. X-axis denotes five categories of macroprudential measures. The vertical lines correspond to 90 percent confidence intervals computed with Driscoll-Kraay standard errors.

These findings indicate that the dampening effects of macroprudential regulation are not driven by a narrow set of measures. In particular, they are not limited to measures targeted at foreign currency exposures that could operate more similarly to capital controls by constraining borrowing in foreign currency. Macroprudential regulation that ensures adequate bank capital and liquidity and prevents excessive risktaking in credit provision also plays a crucial role in fostering resilience to global financial shocks. This suggests that countries that want to enhance the reliance against both VIX and capital flow shocks should adopt a well-rounded macroprudential framework rather than narrowly focusing on few specific measures.

\subsection{Cross-country spillovers}

This section examines if macroprudential regulation generates cross-country spillovers. If a country protects itself from swings in global financial conditions through tight macroprudential regulation, other countries could be exposed to greater volatility. ${ }^{22}$ For example, measures that curb risk taking in a given country could lead to the relocation of risky financial activities to other countries (Houston et al., 2012; Jiménez et al., 2017; McCann and O'Toole, 2019), thus making them more susceptible to global financial shocks. However, macroprudential regulation may also entail positive cross-country spillovers. If a country becomes more resilient to global financial shocks owing to macroprudential regulation, other countries may enjoy greater stability through less volatile trade and financial flows with that country.

\footnotetext{
${ }^{22}$ Similar arguments have been raised regarding capital flow management measures (Lambert et al., 2011, Forbes et al., 2016, Giordani et al., 2017).
} 
To assess possible cross-country spillovers, we extend the specification in equation (1) as follows:

$$
Y_{i, t}=\alpha_{i}+\beta S_{i, t}+\gamma\left(S_{i, t} M \operatorname{Pru}_{i, t}\right)+\bar{\gamma}\left(S_{i, t} \overline{M P r u}_{i, t}\right)+\bar{\zeta} \overline{M P r u}_{i, t}+\kappa C_{i, t}+\varepsilon_{i, t}
$$

Besides interacting the global financial shocks with the level of macroprudential regulation in a given country, the regression includes an interaction term of the shock vector with the average level of regulation $\overline{M P r u}_{i, t}$ in emerging markets other than country $i$. This new interaction term captures if the sensitivity of GDP growth in a given country to global financial shocks is affected by the level of macroprudential regulation in other countries. The average level of regulation $\overline{M P r u}_{i, t}$ is computed by weighting countries according to the average size of gross capital inflows that they received during the sample period. The idea is that countries that are more integrated financially are likely to generate larger spillovers.

Table 6 reports the regression results considering alternative ways to select the countries to be included in the average $\overline{M P r u}_{i, t}$. In column (1), we start by computing $\overline{M P r u}_{i, t}$ using the average level of regulation in all other emerging markets besides the country $i$. We then differentiate countries across several characteristics to capture that spillovers are more likely to occur across similar economies, following Giordani et al. (2017).

In column (2), $\overline{M P r u}_{i, t}$ is computed using only countries within the same geographical region. Columns (3) and (4) differentiate countries based on whether their GDP per capita is above or below the median of the country sample. Column (3) does so by considering the GDP levels in each quarter, so that countries move across groups over time. Column (4) considers instead that average levels of GDP between the 2002/2016 sample period, in which case the group assignment is time invariant. Following the same approach used for GDP, columns (5) and (6) differentiate countries according to their risk class. We use a composite risk index provided by the Political Risk Service that broadly captures the economic, financial, institutional, and political risks of a given country. This index has been used in Giordani et al. (2017) to analyze spillovers from capital flow management measures.

The analysis does not find evidence of negative spillovers. On the contrary, spillovers tend to be positive vis-à-vis net outflows. The coefficient on the interaction between net outflows and the average level of macroprudential regulation in other emerging markets is positive and significant regardless of how the average $\overline{M P r u}_{i, t}$ is computed. This implies that a country becomes more resilient to capital flow shocks if other emerging markets have a higher level of macroprudential regulation.

Regarding the magnitudes, the positive spillover effects associated with capital flow shocks appear sizeable. Across columns (2) to (6) the coefficients on the interaction of net capital outflows with $\overline{M P r u}_{i, t}$ are similar to those on the interaction with each country's level of macroprudential regulation. In other words, countries experience similar dampening effects from their own level of macroprudential regulation than from the average level in other similar countries. However, it is important to recognize that the coefficients on the interaction of net outflows with $\overline{M P r u}_{i, t}$ capture the effect of a one-unit increase in the average level of macroprudential regulation in all other emerging markets within the same group. This is a larger macroprudential tightening than a one-unit increase of an economy's own level of macroprudential regulation. 


\section{Macroprudential regulation and monetary policy}

According to the Mundell-Fleming trilemma, countries that are open to capital flows can retain monetary independence if they have a flexible exchange rate (Fleming, 1962; Mundell, 1963). Monetary independence can be broadly defined as the ability to set interest rates and stabilize domestic macroeconomic conditions independently of swings in global monetary and financial conditions. In line with the trilemma, there is evidence that policy rates in countries with flexible exchange rates are less responsive to US monetary policy and the VIX than in countries with fixed exchange rates (Obstfeld, 2015).

However, even in emerging markets with flexible exchange rates, several central banks tend to increase policy rates in response to a US monetary tightening or a spike in the VIX, even after controlling for inflation (Obstfeld et al., 2005; Aizenman et al., 2016; Aizenman et al., 2017; Han and Wei, 2018; Cavallino and Sandri, 2020; Bhattarai et al., 2020). This is possibly to limit fluctuations in exchange rates and capital flows that may undermine financial stability. In these situations, monetary policy appears to operate procyclically, exacerbating the negative effects of tighter global financial conditions on domestic economic growth.

Against this backdrop, we ask whether macroprudential regulation-by mitigating financial stability concerns - can allow for a more countercyclical monetary policy response to global financial shocks. Some evidence in this favor is provided by Aizenman et al. (2017) who find that a tighter stance of macroprudential policy reduces the sensitivity of policy rates in developing countries to monetary policy conducted in center economies (the US, Japan, and the Euro Area). ${ }^{23}$ We examine this issue further by using a panel regression framework and by considering a broader set of global financial shocks.

The analysis is based on the following panel specification:

$$
I_{i, t}=\alpha_{i}+\beta S_{i, t}+\gamma\left(S_{i, t} \cdot M \operatorname{Pru} u_{i, t}\right)+\zeta M P r u_{i, t}+\kappa C_{i, t}+\varepsilon_{i, t}
$$

where the dependent variable $I_{i, t}$ is the policy rate in a given emerging market $i$ at time $t$. The vector of global shocks $S_{i, t}$ includes the US policy rate, the VIX, and net capital outflows which we instrument as in the previous sections. Note that we use the US policy rate rather than the US policy rate shocks as in Section 2. This is in line with the literature on the trilemma and with the fact that policy rates in emerging markets react to changes in actual US policy rates rather than to their unexpected components (as will be shown in Table 7). The coefficients $\gamma$ capture if the response of domestic monetary policy to global financial shocks is affected by the level of macroprudential regulation. Specifically, negative coefficients would indicate that monetary policy responds more countercyclically to a tightening in global financial conditions when macroprudential regulation is tighter.

The regression specification also includes control variables from an augmented Taylor rule, such as expected inflation over the next 12 months, the output gap, real credit growth, and commodity terms of trade. The inclusion of expected inflation is important to show that monetary policy is not simply responding to the effects of global financial shocks on domestic inflation. We only consider periods in which countries had a flexible exchange rate and thus retain some degree of monetary autonomy. ${ }^{24}$

\footnotetext{
${ }^{23}$ The reduction in interest rate sensitivity is only observed during periods where the center economies conduct expansionary monetary policy.

${ }^{24} \mathrm{~A}$ potential concern about the specification in (5) is that policy rates could be non-stationary. Panel unit root tests by Levin et al. (2002) and Im et al. (2003) reject this hypothesis. Furthermore, the tests by Kao (1999) and Westerlund (2007) reject non-stationarity in the linear combination of the policy rates, output gap, expected inflation, and the global financial shocks. The test results are available upon request.
} 


\subsection{Baseline results}

Table 7 reports the baseline results. We start in column (1) by including only global financial shocks. The results show that policy rates in emerging markets tend to respond pro-cyclically to a tightening in global financial conditions. Specifically, policy rates increase in response to rises in the US policy rate and the VIX, possibly to contain the exchange rate depreciation. Policy rates also increase in response to net capital outflow shocks, likely to attract more foreign investment. These results are broadly consistent with those in the literature (Obstfeld et al., 2005; Aizenman et al., 2016; Aizenman et al., 2017; Han and Wei, 2018; Cavallino and Sandri, 2020; Bhattarai et al., 2020).

Column (2) shows that the monetary policy response remains procyclical when controlling for expected inflation and the output gap. The output gap and expected inflation have the expected signs, with central banks reacting to a higher output gap or expected inflation by tightening monetary policy. These results are robust to controlling for real credit growth and commodity terms of trade in column (3). For all the specifications, the $F$-tests point to instrument validity. Column (4) shows that there is no correlation between emerging markets' policy rates and US monetary policy shocks. This is consistent with an uncovered interest parity logic: if emerging markets aim to stabilize exchange rates and capital flows, they should adjust monetary policy in line with actual US policy rates rather than with the unexpected components.

Column (5) reports the full regression specification, including macroprudential regulation and its interactions with global financial shocks. The estimates show that the interactions with the US policy rate and the VIX are negative and statistically significant. As illustrated in Figure 6, this implies that macroprudential regulation enables monetary policy to respond more countercyclically to global financial shocks. Panel 1 and 2 show that at low levels of macroprudential regulation, emerging markets tighten monetary policy in response to a hike in US monetary policy or an increase in the VIX. A more stringent level of macroprudential regulation dampens this procyclical response. In fact, a sufficiently high level of macroprudential regulation allows central banks in emerging markets to react countercyclically by lowering policy rates when US policy rates and the VIX increase.

Figure 6: Policy Rate Responses in Emerging Markets to Global Financial Shocks
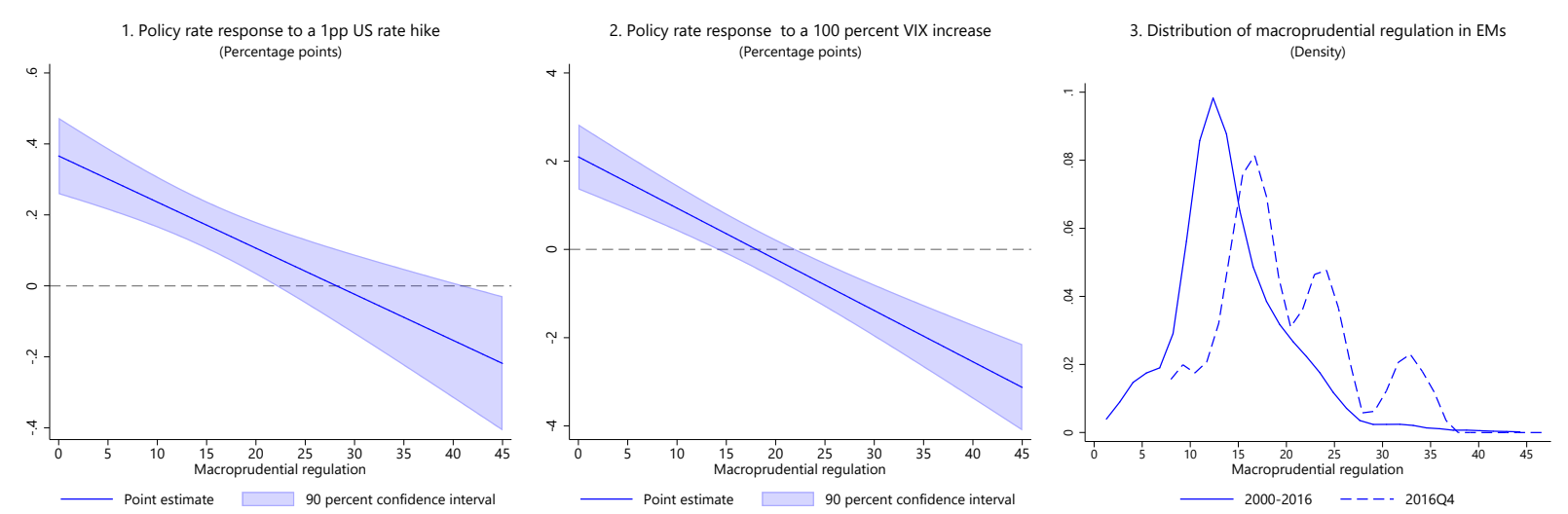

Source: Authors' calculations.

Notes: The x-axis denotes the level of macroprudential regulation. Panels 1 to 2 show the policy rate response to global financial shocks for different levels of macroprudential regulation; panel 3 shows the probability density function of macroprudential regulation in the sample. Net capital outflows are scaled by the HP-trend of GDP. The shaded areas correspond to 90 percent confidence intervals computed with Driscoll-Kraay standard errors. 
Macroprudential regulation can thus support a more countercyclical monetary policy response to US monetary policy and the VIX. However, the results in column (5) of Table 7 also show that macroprudential regulation does not have tangible effects on the monetary policy response to capital outflow shocks. Indeed, capital outflows appear to trigger a monetary tightening in emerging markets independently of the level of macroprudential regulation. This suggests that even in countries with tight macroprudential regulation, central banks continue to face important policy trade-offs in responding to fluctuations in capital flows.

\subsection{Robustness}

In this section we check if the results on the interplay between macroprudential regulation and monetary policy are robust to a broad set of endogeneity tests. There are two primary concerns. First, the results could be affected by reverse causality if countries move macroprudential regulation in response to policy rate changes. For example, this could happen if countries raise macroprudential regulation when policy rates decline to mitigate financial stability concerns from monetary easing. Second, there could be an omitted variable bias if macroprudential regulation correlates with country characteristics and policy tools that affect monetary policy and are not included in the regression.

Table 8 reports the robustness tests to address the reverse causality concern. In columns (1) and (2), we lag the level of macroprudential regulation by one quarter and one year, respectively. In column (3), we use the average level of macroprudential for each country between 2000-2016. In this case, the estimation relies solely on the cross-country variation in regulation, investigating if monetary policy in countries with tighter regulation respond more countercyclically.

Across all these specifications, macroprudential regulation continues to support a more countercyclical response of monetary policy to global financial conditions. The only difference from the baseline results emerges when using the average levels of macroprudential regulation. In this case, regulation supports a more countercyclical response to capital flow shocks rather than to changes in US monetary policy.

Table 9 reports the robustness tests to alleviate concerns about omitted variable bias. In columns (1) to (8), we augment the baseline specification with additional structural and policy variables both in levels and interacted with macroprudential regulation. These include institutional quality (column 1), financial development (column 2), gross public debt (column 3), public debt in foreign currency (column 4), the cyclical adjusted balance (column 5), the anchoring of inflation expectations (column 6), capital controls (column 7), and the level of official reserves in percent of trend GDP (column 8). As in the baseline regression, the coefficients on the interaction of macroprudential regulation and the VIX remain negative and significant in all tests. The interaction coefficients with the US policy rate are also negative and significant, except for the specification augmented with official reserves. In that case, the interaction remains negative but loses statistical significance at the 10 percent level. Finally, column (9) shows that the interaction coefficients with the US policy rates and the VIX remain negative and significant even if we include time fixed effects.

\section{How does macroprudential regulation compare with capital con- trols?}

The previous analysis has shown that macroprudential regulation can significantly dampen the impact of global financial shocks on economic activity in emerging markers (Section 2). Furthermore, it allows monetary 
policy to respond more countercyclically to global financial shocks (Section 3). To put these benefits in perspective, in this section we ask if capital controls can provide similar gains.

The empirical and theoretical literature has placed great emphasis on the role of capital controls in dealing with global financial conditions. ${ }^{25}$ Since these tools directly reduce capital flows, they are expected to limit the sensitivity of emerging markets to global financial shocks. Nonetheless, there are also concerns about their effectiveness. For example, capital controls may "leak", as investors try to circumvent restriction by channeling funds through alternative ways that can prove more volatile. Furthermore, countries that maintain capital controls may signal their willingness to impose new restrictions during a crisis. This could unnerve foreign investors and lead to higher volatility.

To assess the possible benefits from capital controls, we replicate the analysis in the previous sections using four different indicators of capital controls from Chinn and Ito (2008), Fernández et al. (2015), Quinn and Toyoda (2008), and Pasricha et al. (2018). ${ }^{26}$ The goal is to examine if, for at least one of these indicators, there is systemic evidence that more stringent capital control restrictions provide similar or greater benefits to those from a tighter level of macroprudential regulation. ${ }^{27}$

We start by analyzing if capital controls can dampen the effects of global financial shocks on GDP in emerging markets. To do so, we re-estimate equation (1) using the indexes of capital controls instead of macroprudential regulation. Table 10 reports the results, using specifications with and without quadratic terms for capital controls. We denote the stringency of capital controls with $C C$.

Across all specifications from column (1) to (8), we confirm that an increase in the VIX or a capital outflow have negative effects on GDP growth in emerging markets. A more stringent level of capital controls would dampen these effects if the coefficient estimates on the interaction terms between capital controls and the shocks are positive. We do not find any systematic evidence that this is the case. Most coefficients are insignificant. Some are even negative and statistically significant, thus suggesting the capital controls may actually exacerbate the transmission of global financial shocks. The interaction coefficients are positive and weakly statistically significant only in column (3) against the VIX and in column (7) against net capital outflows. Overall, the results suggest that the stringency of capital controls does not affect the impact of global financial shocks on economic activity in emerging markets. This is in sharp contrast with the results on macroprudential regulation. ${ }^{28}$

We also explore if capital controls have clearer dampening effects against global financial shocks when we distinguish between controls on capital inflows and controls on capital outflows. This distinction is possible only using the indexes provided by Fernández et al. (2015) and Pasricha et al. (2018). The results are

\footnotetext{
${ }^{25}$ See the recent comprehensive reviews of the literature provided by Erten et al. (2019) and Rebucci and Ma (2019).

${ }^{26}$ The indices by Chinn and Ito (2008), Fernández et al. (2015), and Quinn and Toyoda (2008) capture the level of capital controls by counting how many capital control measures are active. The index by Pasricha et al. (2018) measures instead changes in capital controls over time. In this case, we cumulate net tightening actions to create an index for the stringency of capital controls at each point in time. This is the same approach that we used to construct our index of the stringency of macroprudential regulation.

${ }^{27} \mathrm{As}$ in the case of macroprudential regulation, the analysis refrains from exploring how changes in capital controls affect macroeconomic outcomes in emerging markets. This is a more challenging question that is subject to severe identification challenges due to the endogeneity of policy responses.

${ }^{28}$ The literature finds mixed results on the effects of capital controls on macro outcomes. On the one hand, Klein (2012) finds that, after controlling for GDP per capita, countries with capital controls - no matter whether they are long-standing or used episodically - do not experience slower growth of financial variables associated with asset price bubbles. Using a propensity-score matching methodology, Forbes et al. (2015) find that most capital controls have no significant effects on macro variables. On the other hand, Erten and Ocampo (2017) document that countries that tightened capital controls before the global financial crises experienced more moderate recessions. Furthermore, Zeev (2017) finds that GDP in countries with stricter controls on capital inflows responds less to global credit supply shocks.
} 
reported in Table 11 and, again, do not show any systemic pattern. Most coefficients on the interaction terms between capital controls and the shocks are insignificant. There are three cases where the coefficients are positive and significant, but there is an equal number of negative coefficients. ${ }^{29}$

We now turn to the question of whether capital controls can enable countries to conduct a more countercyclical monetary policy in response to global financial shocks. We re-estimate equation (5) by replacing the index of macroprudential regulation with capital control measures. If stricter capital controls allow for a more countercyclical monetary policy response, the coefficients on the interactions between capital controls and the shocks should be negative and statistically significant.

Table 12 reports the regression results. We do not find evidence that more stringent capital controls support a more countercyclical monetary policy response. Most coefficients on the interaction terms in columns (1) to (4) are insignificant. Only the interaction with the US policy rate in column (4) is negative and weakly significant. There are also several instances in columns (1) and (2) where the coefficients are positive and strongly significant, thus suggesting that tighter capital controls are associated with a more procyclical response of monetary policy. Table 13 reports similar findings when we differentiate capital controls on inflows and outflows.

The lack of systematic effects of capital controls on monetary policy could appear in contradiction with earlier contributions to the literature. Shambaugh (2004) finds that capital controls reduce the comovement of domestic policy rates with the interest rate in a foreign base country using data between 1973 and 2000 . Our analysis considers the period post 2000 when international capital markets have become considerably more integrated, possibly allowing investors to more easily circumvent capital controls. Han and Wei (2018) also document that capital controls reduce the comovement between policy rates in emerging and advanced economies and the US policy rate. However, their results apply especially to countries with fixed exchange rates. ${ }^{30}$ Similarly, Aizenman et al. (2016) find that capital controls reduce the sensitivity of policy rates in emerging markets to monetary policy in major economies, but do not allow the effect to differ across exchange rate regimes. Our regression analysis considers instead only countries that have flexible exchange rates and that should therefore already enjoy a significant degree of monetary independence. In this case, capital controls do not seem to provide additional benefits for monetary policy. Furthermore, our analysis features a broader set of global financial shocks relative to the literature, including not only US monetary policy but also movements in the VIX and shocks to capital inflows.

Overall, the results suggest that a tighter level of capital controls does not help emerging markets to dampen global financial shocks nor it supports a more countercyclical monetary policy response. Against this background, the strength of the results on the benefits of macroprudential regulation appears even more notable.

The fact that the regression analysis did not find significant effects associated capital controls should not be used to dismiss possible gains from these tools. Restrictions on capital account transactions could be helpful in case of very large global shocks. Furthermore, in line with the approach used to examine macroprudential regulation, we have only tested if a more stringent level of capital controls affects the transmission of global financial shocks and the monetary policy response. The gains from capital controls

\footnotetext{
${ }^{29}$ It is also worth noticing that the $F$-statistic is quite low when using capital controls on inflows and outflows from Pasricha et al. (2018), also because of the smaller country sample.

${ }^{30}$ This can been seen in columns (3) to (6) of their Table 7 that use continuous measures of capital controls in line with our analysis. Han and Wei (2018) also find that capital controls reduce the sensitivity of policy rates to US monetary policy in countries with flexible exchange rates when using a dummy variable capturing the existence of capital controls. We can replicate their findings if we restrict the analysis to their country and period sample that stops in 2009.
} 
could instead materialize only by optimally adjusting capital controls in response to shocks. This is indeed the perspective developed in the recent theoretical models whereby capital controls should lean against systemic risks associated with domestic and external developments.

\section{Conclusions}

The key result of the paper is that macroprudential regulation can significantly dampen the macroeconomic impacts of global financial shocks on emerging markets. More specifically, a tighter level of regulation reduces the sensitivity of GDP growth in emerging markets to fluctuations in risk premia and changes in the supply of international capital flows. The dampening effects are symmetric, reducing the effects on GDP from both positive and negative global financial shocks. Therefore, while more stringent regulation leads to a lower decline in GDP when global financial conditions tighten, it also constrains economic activity when global financial conditions are buoyant.

The dampening effects of macroprudential regulation are not driven by a narrow set of instruments. A broad range of macroprudential measures targeting liquidity, capital, foreign exchange exposures, and risky forms of credit contribute to enhancing macroeconomic resilience to global financial shocks. The effects of specific measures are heterogeneous and depend on the specific type of financial shock hitting the economy.

The analysis does not find evidence of negative cross-country spillovers from macroprudential regulation. On the contrary, a higher level of macroprudential regulation in one country appears to also strengthen resilience to capital flow shocks in other countries. This is possibly because, if a country uses macroprudential measures to enhance macroeconomic stability, other countries may benefit through more stable trade and financial linkages.

One possible channel through which macroprudential regulation strengthens macroeconomic resilience is by allowing monetary policy to respond more countercyclically to global financial shocks. The empirical evidence suggests that at low levels of macroprudential regulation, central banks in emerging markets tend to increase policy rates when global financial conditions tighten. This is likely because of financial stability concerns arising from movements in exchange rates and capital outflows. However, at higher levels of macroprudential regulation, central banks tend to lower policy rates when global financial conditions tighten, thus cushioning the impact of adverse financial shocks on domestic economic growth.

The benefits of macroprudential regulation uncovered in the analysis are particularly notable since we do not find evidence that capital controls provide similar gains. Despite using various measures of capital controls, the impact of global financial shocks on emerging markets' GDP is not systematically affected by the stringency of capital flow restrictions. Furthermore, the stringency of capital controls does not support a more countercyclical response of monetary policy to global financial conditions.

Therefore, the findings of the analysis suggests that a sound macroprudential regulatory framework may go a long way in helping emerging markets to strengthen resilience against global financial shocks. To maximize the benefits of macroprudential regulation, policymakers should consider using a broad range of measures rather than focusing on a narrow set of tools. Imposing capital controls to limit cross-border financial transactions does not appear to be a valid substitute to adopting a solid macroprudential framework. 
Table 1: Dampening Effects of Macroprudential Regulation on GDP Growth

\begin{tabular}{|c|c|c|c|c|c|}
\hline & All EMs & All EMs & All EMs & No fixed ER & All EMs \\
\hline & (1) & $(2)$ & $(3)$ & (4) & (5) \\
\hline Lag dependent variable & $\begin{array}{c}0.071 \\
(0.057)\end{array}$ & $\begin{array}{c}0.117 \\
(0.088)\end{array}$ & $\begin{array}{c}0.072 \\
(0.050)\end{array}$ & $\begin{array}{c}0.012 \\
(0.054)\end{array}$ & $\begin{array}{c}0.072 \\
(0.048)\end{array}$ \\
\hline Lag output gap & $\begin{array}{c}-0.378^{* * *} \\
(0.035)\end{array}$ & $\begin{array}{c}-0.313^{* * *} \\
(0.045)\end{array}$ & $\begin{array}{c}-0.369^{* * *} \\
(0.035)\end{array}$ & $\begin{array}{c}-0.342^{* * *} \\
(0.033)\end{array}$ & $\begin{array}{c}-0.368^{* * *} * \\
(0.035)\end{array}$ \\
\hline Lag ln real GDP per capita & $\begin{array}{c}-0.880^{*} \\
(0.505)\end{array}$ & $\begin{array}{l}-0.144 \\
(0.440)\end{array}$ & $\begin{array}{c}-1.689^{* *} \\
(0.707)\end{array}$ & $\begin{array}{c}-1.111^{*} \\
(0.630)\end{array}$ & $\begin{array}{c}-1.713^{* *} \\
(0.749)\end{array}$ \\
\hline Institutional quality & $\begin{array}{l}-0.281 \\
(0.644)\end{array}$ & $\begin{array}{l}-0.484 \\
(0.455)\end{array}$ & $\begin{array}{l}-0.132 \\
(0.813)\end{array}$ & $\begin{array}{l}-0.536 \\
(0.938)\end{array}$ & $\begin{array}{c}0.078 \\
(0.930)\end{array}$ \\
\hline Linear trend & $\begin{array}{c}0.003 \\
(0.005)\end{array}$ & $\begin{array}{l}-0.002 \\
(0.005)\end{array}$ & $\begin{array}{c}0.005 \\
(0.007)\end{array}$ & $\begin{array}{c}0.002 \\
(0.006)\end{array}$ & $\begin{array}{c}0.002 \\
(0.007)\end{array}$ \\
\hline Commodity terms of trade & $\begin{array}{c}0.050 \\
(0.035)\end{array}$ & $\begin{array}{c}0.056 \\
(0.038)\end{array}$ & $\begin{array}{c}0.037 \\
(0.050)\end{array}$ & $\begin{array}{c}0.083 \\
(0.052)\end{array}$ & $\begin{array}{c}0.035 \\
(0.058)\end{array}$ \\
\hline US monetary policy shock & $\begin{array}{l}-0.158 \\
(0.168)\end{array}$ & $\begin{array}{c}-0.449^{* *} \\
(0.189)\end{array}$ & $\begin{array}{l}-0.008 \\
(0.311)\end{array}$ & $\begin{array}{l}-0.077 \\
(0.318)\end{array}$ & $\begin{array}{c}0.017 \\
(0.357)\end{array}$ \\
\hline Ln VIX & $\begin{array}{c}-0.712^{* * *} \\
(0.182)\end{array}$ & & $\begin{array}{c}-1.556^{* * *} \\
(0.312)\end{array}$ & $\begin{array}{c}-1.571^{* * *} \\
(0.287)\end{array}$ & $\begin{array}{c}-1.762^{* * *} \\
(0.487)\end{array}$ \\
\hline Net outflows & $\begin{array}{c}-0.186^{* * *} \\
(0.046)\end{array}$ & & $\begin{array}{c}-0.393^{* * *} \\
(0.113)\end{array}$ & $\begin{array}{c}-0.378^{* * *} \\
(0.122)\end{array}$ & $\begin{array}{c}-0.624^{* * *} \\
(0.183)\end{array}$ \\
\hline Mpru & & & $\begin{array}{c}-1.380^{* * *} \\
(0.401)\end{array}$ & $\begin{array}{c}-1.480^{* * *} \\
(0.404)\end{array}$ & $\begin{array}{l}-1.514 \\
(1.234)\end{array}$ \\
\hline US monetary policy shock $*$ Mpru & & & $\begin{array}{c}-0.100 \\
(0.109)\end{array}$ & $\begin{array}{c}-0.074 \\
(0.118)\end{array}$ & $\begin{array}{l}-0.164 \\
(0.221)\end{array}$ \\
\hline Ln VIX * Mpru & & & $\begin{array}{c}0.631^{* * *} \\
(0.143)\end{array}$ & $\begin{array}{c}0.609 * * * \\
(0.148)\end{array}$ & $\begin{array}{c}0.997^{* *} \\
(0.419)\end{array}$ \\
\hline Net outflows * Mpru & & & $\begin{array}{c}0.108^{* * *} * \\
(0.036)\end{array}$ & $\begin{array}{c}0.095^{* *} \\
(0.043)\end{array}$ & $\begin{array}{c}0.319^{* * * *} \\
(0.111)\end{array}$ \\
\hline MPru2 & & & & & $\begin{array}{c}0.237 \\
(0.209)\end{array}$ \\
\hline US monetary policy shock * MPru2 & & & & & $\begin{array}{c}0.037 \\
(0.037)\end{array}$ \\
\hline Ln VIX $*$ MPru2 & & & & & $\begin{array}{c}-0.129^{*} \\
(0.073)\end{array}$ \\
\hline Net outflows $*$ MPru 2 & & & & & $\begin{array}{c}-0.040^{* *} \\
(0.016)\end{array}$ \\
\hline Observations & 2,260 & 2,260 & 2,260 & 1,658 & 2,260 \\
\hline Countries & 38 & 38 & 38 & 32 & 38 \\
\hline F-statistic & 73.1 & & 33.1 & 24.4 & 18.6 \\
\hline
\end{tabular}

Source: Authors' calculations.

Notes: Net inflows (in percent of trend GDP) for each country are instrumented using gross inflows to other EMs (in percent of trend GDP). Results are presented in terms of net outflows. MPru is divided by 10 to ease the visualization of the coefficients. The estimations are based on a sample of EM from 2000Q1 to 2016Q4. All specifications include country fixed effects. Driscoll-Kraay standard errors are reported in parentheses. ${ }^{* * *},{ }^{*}$, and $*$ indicate statistical significance at 1,5 , and 10 percent, respectively. 
Table 2: Robustness for Reverse Causality: Dampening Effects on GDP Growth

\begin{tabular}{|c|c|c|c|c|}
\hline & $\begin{array}{l}\text { Excluding } \\
\text { negative } \\
\text { GDP } \\
\text { growth }\end{array}$ & $\begin{array}{l}\text { MPru= } \\
\text { one-quarter } \\
\text { lag of } \\
\text { MPru }\end{array}$ & $\begin{array}{l}\text { MPru = } \\
\text { One-year } \\
\text { lag of } \\
\text { MPru }\end{array}$ & $\begin{array}{l}\text { MPru = } \\
\text { country } \\
\text { average of } \\
\text { MPru }\end{array}$ \\
\hline & $(1)$ & $(2)$ & (3) & $(4)$ \\
\hline Lag dependent variable & $\begin{array}{c}-0.054 \\
(0.039)\end{array}$ & $\begin{array}{c}0.076 \\
(0.051)\end{array}$ & $\begin{array}{c}0.076 \\
(0.054)\end{array}$ & $\begin{array}{c}0.079 \\
(0.052)\end{array}$ \\
\hline Lag output gap & $\begin{array}{c}-0.180^{* * *} \\
(0.024)\end{array}$ & $\begin{array}{c}-0.367^{* * *} \\
(0.035)\end{array}$ & $\begin{array}{c}-0.353^{* * *} \\
(0.034)\end{array}$ & $\begin{array}{c}-0.368^{* * *} \\
(0.035)\end{array}$ \\
\hline Lag ln real GDP per capita & $\begin{array}{c}-0.791^{*} \\
(0.474)\end{array}$ & $\begin{array}{c}-1.608^{* *} \\
(0.736)\end{array}$ & $\begin{array}{c}-1.833^{* *} \\
(0.822)\end{array}$ & $\begin{array}{c}-1.675^{* *} \\
(0.754)\end{array}$ \\
\hline Institutional quality & $\begin{array}{l}-0.650 \\
(0.501)\end{array}$ & $\begin{array}{l}-0.197 \\
(0.813)\end{array}$ & $\begin{array}{c}-0.541 \\
(0.811)\end{array}$ & $\begin{array}{l}-0.343 \\
(0.766)\end{array}$ \\
\hline Linear trend & $\begin{array}{c}-0.002 \\
(0.005)\end{array}$ & $\begin{array}{l}0.005 \\
(0.007)\end{array}$ & $\begin{array}{c}0.010 \\
(0.008)\end{array}$ & $\begin{array}{c}0.007 \\
(0.007)\end{array}$ \\
\hline Commodity terms of trade & $\begin{array}{l}0.079^{*} \\
(0.048)\end{array}$ & $\begin{array}{c}0.039 \\
(0.050)\end{array}$ & $\begin{array}{c}0.041 \\
(0.055)\end{array}$ & $\begin{array}{c}0.052 \\
(0.039)\end{array}$ \\
\hline US monetary policy shock & $\begin{array}{c}0.207 \\
(0.166)\end{array}$ & $\begin{array}{l}-0.013 \\
(0.298)\end{array}$ & $\begin{array}{l}-0.008 \\
(0.265)\end{array}$ & $\begin{array}{l}-0.046 \\
(0.314)\end{array}$ \\
\hline Ln VIX & $\begin{array}{c}-0.597^{* * *} \\
(0.221)\end{array}$ & $\begin{array}{c}-1.504^{* * * *} \\
(0.305)\end{array}$ & $\begin{array}{c}-1.498^{* * *} \\
(0.298)\end{array}$ & $\begin{array}{c}-1.356^{* * *} \\
(0.402)\end{array}$ \\
\hline Net outflows & $\begin{array}{c}-0.258^{* * *} \\
(0.071)\end{array}$ & $\begin{array}{c}-0.396^{* * *} \\
(0.111)\end{array}$ & $\begin{array}{c}-0.424^{* * *} \\
(0.108)\end{array}$ & $\begin{array}{c}-0.444^{* * *} \\
(0.151)\end{array}$ \\
\hline MPru & $\begin{array}{c}-0.639^{* *} \\
(0.323)\end{array}$ & $\begin{array}{c}-1.286^{* * *} \\
(0.375)\end{array}$ & $\begin{array}{c}-1.534^{* * *} \\
(0.388)\end{array}$ & \\
\hline US monetary policy shock * MPru & $\begin{array}{c}-0.120^{*} \\
(0.068)\end{array}$ & $\begin{array}{l}-0.101 \\
(0.100)\end{array}$ & $\begin{array}{l}-0.133 \\
(0.090)\end{array}$ & $\begin{array}{c}-0.070 \\
(0.116)\end{array}$ \\
\hline Ln VIX * MPru & $\begin{array}{c}0.259^{* *} \\
(0.120)\end{array}$ & $\begin{array}{c}0.598^{* * *} \\
(0.133)\end{array}$ & $\begin{array}{c}0.683^{* * *} \\
(0.137)\end{array}$ & $\begin{array}{c}0.444^{* *} \\
(0.208)\end{array}$ \\
\hline Net outflows * MPru & $\begin{array}{c}0.067^{* * *} \\
(0.024)\end{array}$ & $\begin{array}{c}0.111^{* * *} \\
(0.035)\end{array}$ & $\begin{array}{c}0.125^{* * *} \\
(0.035)\end{array}$ & $\begin{array}{c}0.149^{* *} \\
(0.062)\end{array}$ \\
\hline Observations & 1,846 & 2,235 & 2,153 & 2,260 \\
\hline Countries & 38 & 38 & 38 & 38 \\
\hline$F$-statistic & 35.1 & 32.9 & 32.6 & 29.7 \\
\hline
\end{tabular}

Source: Authors' calculations.

Notes: Net inflows (in percent of trend GDP) for each country are instrumented using gross inflows to other EMs (in percent of trend GDP). Results are presented in terms of net outflows. MPru is divided by 10 to ease the visualization of the coefficients. The estimations are based on a sample of EM from 2000Q1 to 2016Q4. All specifications include country fixed effects. Driscoll-Kraay standard errors are reported in parentheses. ***, **, and * indicate statistical significance at 1, 5, and 10 percent, respectively. 
Table 3: Robustness Tests for Omitted Variables, Dampening Effects on GDP Growth

\begin{tabular}{|c|c|c|c|c|c|c|c|c|c|c|c|}
\hline & $\begin{array}{l}\mathrm{X}=\text { institu- } \\
\text { tional qual- } \\
\text { ity }\end{array}$ & $\begin{array}{l}\mathrm{X}=\mathrm{fi-} \\
\text { nancial } \\
\text { develop- } \\
\text { ment }\end{array}$ & $\begin{array}{l}\mathrm{X}=\text { gross } \\
\text { public debt }\end{array}$ & $\begin{array}{l}\mathrm{X}=\text { gross } \\
\text { public debt } \\
\text { in foreign } \\
\text { currency }\end{array}$ & $\begin{array}{l}\mathrm{X}=\text { cycli- } \\
\text { cally ad- } \\
\text { justed } \\
\text { balance }\end{array}$ & $\begin{array}{l}\mathrm{X}=\text { mon- } \\
\text { etary policy } \\
\text { rate }\end{array}$ & $\begin{array}{l}\mathrm{X}=\text { in- } \\
\text { flation } \\
\text { expectation } \\
\text { anchoring }\end{array}$ & $\begin{array}{l}\mathrm{X}=\text { fixed } \\
\mathrm{ER} \text { regime }\end{array}$ & $\begin{array}{l}\mathrm{X}=\text { cap- } \\
\text { ital flow } \\
\text { measures }\end{array}$ & $\begin{array}{l}\mathrm{X}=\text { official } \\
\text { reserves }\end{array}$ & $\begin{array}{l}\text { Including } \\
\text { time fixed } \\
\text { effects }\end{array}$ \\
\hline & (1) & (2) & (3) & (4) & (5) & (6) & (7) & (8) & (9) & (10) & (11) \\
\hline Lag dependent variable & $\begin{array}{c}0.071 \\
(0.050)\end{array}$ & $\begin{array}{c}0.064 \\
(0.050)\end{array}$ & $\begin{array}{c}0.059 \\
(0.051)\end{array}$ & $\begin{array}{l}0.090^{*} \\
(0.050)\end{array}$ & $\begin{array}{c}0.103^{* *} \\
(0.049)\end{array}$ & $\begin{array}{c}0.085 \\
(0.060)\end{array}$ & $\begin{array}{c}0.221 * * * \\
(0.071)\end{array}$ & $\begin{array}{c}0.071 \\
(0.049)\end{array}$ & $\begin{array}{l}0.120^{* *} \\
(0.047)\end{array}$ & $\begin{array}{c}0.072 \\
(0.052)\end{array}$ & $\begin{array}{c}0.058 \\
(0.059)\end{array}$ \\
\hline Lag output gap & $\begin{array}{c}-0.370^{* * *} \\
(0.035)\end{array}$ & $\begin{array}{c}-0.371^{* * *} * \\
(0.035)\end{array}$ & $\begin{array}{c}-0.373^{* * *} \\
(0.037)\end{array}$ & $\begin{array}{c}-0.350 * * * \\
(0.034)\end{array}$ & $\begin{array}{c}-0.316^{* * *} * \\
(0.024)\end{array}$ & $\begin{array}{c}-0.326^{* * *} \\
(0.037)\end{array}$ & $\begin{array}{c}-0.252^{* * * *} \\
(0.053)\end{array}$ & $\begin{array}{c}-0.372^{* * *} \\
(0.036)\end{array}$ & $\begin{array}{c}-0.325 * * * \\
(0.029)\end{array}$ & $\begin{array}{c}-0.373^{* * *} \\
(0.038)\end{array}$ & $\begin{array}{c}-0.401^{* * *} \\
(0.034)\end{array}$ \\
\hline Lag ln real GDP per capita & $\begin{array}{c}-1.758^{* *} \\
(0.774)\end{array}$ & $\begin{array}{l}-1.405^{*} \\
(0.805)\end{array}$ & $\begin{array}{c}-1.584^{* *} \\
(0.720)\end{array}$ & $\begin{array}{l}-0.794 \\
(0.723)\end{array}$ & $\begin{array}{l}-0.764 \\
(0.587)\end{array}$ & $\begin{array}{c}-2.705^{* *} \\
(1.086)\end{array}$ & $\begin{array}{l}-5.289 \\
(3.605)\end{array}$ & $\begin{array}{c}-1.509^{* *} \\
(0.673)\end{array}$ & $\begin{array}{c}-1.164^{*} \\
(0.639)\end{array}$ & $\begin{array}{l}-1.437^{*} \\
(0.749)\end{array}$ & $\begin{array}{l}-0.660 \\
(0.467)\end{array}$ \\
\hline Institutional quality & $\begin{array}{c}0.433 \\
(1.232)\end{array}$ & $\begin{array}{l}-0.077 \\
(0.887)\end{array}$ & $\begin{array}{l}-0.284 \\
(0.718)\end{array}$ & $\begin{array}{l}-0.112 \\
(0.840)\end{array}$ & $\begin{array}{c}0.097 \\
(0.582)\end{array}$ & $\begin{array}{l}-0.449 \\
(0.659)\end{array}$ & $\begin{array}{c}0.432 \\
(1.001)\end{array}$ & $\begin{array}{l}-0.182 \\
(0.797)\end{array}$ & $\begin{array}{l}-0.564 \\
(0.810)\end{array}$ & $\begin{array}{l}-0.395 \\
(0.772)\end{array}$ & $\begin{array}{l}-0.844^{*} \\
(0.446)\end{array}$ \\
\hline Linear trend & $\begin{array}{c}0.006 \\
(0.007)\end{array}$ & $\begin{array}{c}0.008 \\
(0.008)\end{array}$ & $\begin{array}{c}0.007 \\
(0.007)\end{array}$ & $\begin{array}{c}0.003 \\
(0.007)\end{array}$ & $\begin{array}{c}0.003 \\
(0.006)\end{array}$ & $\begin{array}{c}0.006 \\
(0.010)\end{array}$ & $\begin{array}{c}0.029 \\
(0.025)\end{array}$ & $\begin{array}{c}0.004 \\
(0.007)\end{array}$ & $\begin{array}{c}0.002 \\
(0.006)\end{array}$ & $\begin{array}{l}-0.000 \\
(0.007)\end{array}$ & \\
\hline Commodity terms of trade & $\begin{array}{c}0.035 \\
(0.048)\end{array}$ & $\begin{array}{c}0.034 \\
(0.058)\end{array}$ & $\begin{array}{c}0.007 \\
(0.051)\end{array}$ & $\begin{array}{c}0.056 \\
(0.051)\end{array}$ & $\begin{array}{c}0.041 \\
(0.029)\end{array}$ & $\begin{array}{c}0.016 \\
(0.036)\end{array}$ & $\begin{array}{l}-0.172 \\
(0.190)\end{array}$ & $\begin{array}{c}0.034 \\
(0.053)\end{array}$ & $\begin{array}{c}0.028 \\
(0.047)\end{array}$ & $\begin{array}{c}0.071 \\
(0.045)\end{array}$ & $\begin{array}{l}0.047^{*} \\
(0.026)\end{array}$ \\
\hline US monetary policy shock & $\begin{array}{c}0.038 \\
(0.323)\end{array}$ & $\begin{array}{c}0.359 \\
(0.376)\end{array}$ & $\begin{array}{l}-0.295 \\
(0.407)\end{array}$ & $\begin{array}{l}-0.030 \\
(0.148)\end{array}$ & $\begin{array}{l}-0.338 \\
(0.247)\end{array}$ & $\begin{array}{c}0.328 \\
(0.377)\end{array}$ & $\begin{array}{l}-0.021 \\
(0.389)\end{array}$ & $\begin{array}{l}-0.017 \\
(0.293)\end{array}$ & $\begin{array}{l}-0.042 \\
(0.361)\end{array}$ & $\begin{array}{c}0.009 \\
(0.254)\end{array}$ & \\
\hline Ln VIX & $\begin{array}{c}-1.623^{* * *} \\
(0.326)\end{array}$ & $\begin{array}{c}-2.169^{* * *} \\
(0.488)\end{array}$ & $\begin{array}{l}-1.265^{*} \\
(0.649)\end{array}$ & $\begin{array}{c}-1.372^{* * *} \\
(0.418)\end{array}$ & $\begin{array}{c}-1.294^{* * *} \\
(0.299)\end{array}$ & $\begin{array}{c}-1.999^{* * *} \\
(0.656)\end{array}$ & $\begin{array}{c}-1.555^{* * *} \\
(0.484)\end{array}$ & $\begin{array}{c}-1.540^{* * *} \\
(0.282)\end{array}$ & $\begin{array}{c}-1.996 * * * \\
(0.324)\end{array}$ & $\begin{array}{c}-1.592^{* * *} \\
(0.343)\end{array}$ & \\
\hline Net outflows & $\begin{array}{c}-0.412^{* * * *} \\
(0.120)\end{array}$ & $\begin{array}{c}-0.410 \text { *** } \\
(0.109)\end{array}$ & $\begin{array}{c}-0.552^{* * * *} \\
(0.160)\end{array}$ & $\begin{array}{c}-0.491 * * * \\
(0.141)\end{array}$ & $\begin{array}{c}-0.251^{* * * *} \\
(0.091)\end{array}$ & $\begin{array}{c}-0.302^{* *} \\
(0.126)\end{array}$ & $\begin{array}{c}-0.358^{* *} \\
(0.157)\end{array}$ & $\begin{array}{c}-0.419^{* * *} \\
(0.112)\end{array}$ & $\begin{array}{c}-0.321^{* * *} \\
(0.094)\end{array}$ & $\begin{array}{c}-0.525^{* * *} \\
(0.132)\end{array}$ & $\begin{array}{c}-0.108^{* * *} \\
(0.032)\end{array}$ \\
\hline MPru & $\begin{array}{c}-1.412^{* * * *} \\
(0.418)\end{array}$ & $\begin{array}{c}-1.285^{* * *} \\
(0.435)\end{array}$ & $\begin{array}{c}-1.439^{* * *} \\
(0.464)\end{array}$ & $\begin{array}{c}-1.428 * * * \\
(0.355)\end{array}$ & $\begin{array}{c}-1.402^{* * *} \\
(0.405)\end{array}$ & $\begin{array}{c}-1.399^{* * *} \\
(0.467)\end{array}$ & $\begin{array}{c}-1.679^{* *} \\
(0.808)\end{array}$ & $\begin{array}{c}-1.348^{* * * *} \\
(0.412)\end{array}$ & $\begin{array}{c}-1.357^{* * *} \\
(0.343)\end{array}$ & $\begin{array}{c}-1.128^{* * *} \\
(0.435)\end{array}$ & $\begin{array}{c}-1.090^{* * *} \\
(0.402)\end{array}$ \\
\hline US monetary policy shock * MPru & $\begin{array}{l}-0.108 \\
(0.115)\end{array}$ & $\begin{array}{l}-0.105 \\
(0.107)\end{array}$ & $\begin{array}{l}-0.111 \\
(0.129)\end{array}$ & $\begin{array}{l}-0.069 \\
(0.075)\end{array}$ & $\begin{array}{c}0.012 \\
(0.081)\end{array}$ & $\begin{array}{l}-0.125 \\
(0.123)\end{array}$ & $\begin{array}{l}-0.109 \\
(0.145)\end{array}$ & $\begin{array}{l}-0.087 \\
(0.104)\end{array}$ & $\begin{array}{l}-0.058 \\
(0.098)\end{array}$ & $\begin{array}{l}-0.011 \\
(0.098)\end{array}$ & $\begin{array}{l}-0.003 \\
(0.073)\end{array}$ \\
\hline Ln VIX * MPru & $\begin{array}{c}0.644^{* * *} \\
(0.152)\end{array}$ & $\begin{array}{c}0.627^{* * *} \\
(0.149)\end{array}$ & $\begin{array}{c}0.620^{* * *} \\
(0.171)\end{array}$ & $\begin{array}{c}0.641^{* * *} \\
(0.131)\end{array}$ & $\begin{array}{c}0.559^{* * *} \\
(0.148)\end{array}$ & $\begin{array}{c}0.652^{* * *} \\
(0.172)\end{array}$ & $\begin{array}{l}0.816^{* *} \\
(0.341)\end{array}$ & $\begin{array}{c}0.615^{* * *} \\
(0.148)\end{array}$ & $\begin{array}{c}0.575^{* * *} \\
(0.121)\end{array}$ & $\begin{array}{c}0.522^{* * *} \\
(0.150)\end{array}$ & $\begin{array}{c}0.449^{* * *} \\
(0.156)\end{array}$ \\
\hline Net outflows * MPru & $\begin{array}{c}0.117^{* * *} \\
(0.042)\end{array}$ & $\begin{array}{c}0.124^{* * *} \\
(0.043)\end{array}$ & $\begin{array}{c}0.131^{* * *} \\
(0.042)\end{array}$ & $\begin{array}{c}0.101^{* * * *} \\
(0.032)\end{array}$ & $\begin{array}{c}0.065^{* *} \\
(0.029)\end{array}$ & $\begin{array}{c}0.094^{* *} \\
(0.040)\end{array}$ & $\begin{array}{l}0.097^{*} \\
(0.051)\end{array}$ & $\begin{array}{c}0.102^{* * *} \\
(0.035)\end{array}$ & $\begin{array}{c}0.091^{* * *} \\
(0.031)\end{array}$ & $\begin{array}{c}0.064^{* *} \\
(0.028)\end{array}$ & $\begin{array}{l}0.025^{*} \\
(0.014)\end{array}$ \\
\hline US monetary policy shock $* \mathrm{X}$ & $\begin{array}{c}0.207 \\
(0.128)\end{array}$ & $\begin{array}{c}-0.999^{* *} \\
(0.455)\end{array}$ & $\begin{array}{c}0.007^{* * *} \\
(0.003)\end{array}$ & $\begin{array}{l}-0.164 \\
(0.444)\end{array}$ & $\begin{array}{l}-0.008 \\
(0.017)\end{array}$ & $\begin{array}{l}-0.053^{*} \\
(0.031)\end{array}$ & $\begin{array}{l}-0.118 \\
(0.482)\end{array}$ & $\begin{array}{l}-0.002 \\
(0.104)\end{array}$ & $\begin{array}{l}-0.117 \\
(0.212)\end{array}$ & $\begin{array}{l}-0.008 \\
(0.005)\end{array}$ & \\
\hline Ln VIX * X & $\begin{array}{l}-0.242 \\
(0.272)\end{array}$ & $\begin{array}{c}1.937 \\
(1.193)\end{array}$ & $\begin{array}{l}-0.005 \\
(0.010)\end{array}$ & $\begin{array}{l}-0.476 \\
(0.589)\end{array}$ & $\begin{array}{c}0.005 \\
(0.032)\end{array}$ & $\begin{array}{c}0.074 \\
(0.081)\end{array}$ & $\begin{array}{l}-2.203 \\
(1.631)\end{array}$ & $\begin{array}{l}-0.026 \\
(0.280)\end{array}$ & $\begin{array}{l}1.223^{* *} \\
(0.492)\end{array}$ & $\begin{array}{c}0.007 \\
(0.011)\end{array}$ & \\
\hline Net outflows * X & $\begin{array}{c}0.043 \\
(0.081)\end{array}$ & $\begin{array}{c}0.080 \\
(0.270)\end{array}$ & $\begin{array}{l}-0.003 \\
(0.002)\end{array}$ & $\begin{array}{l}-0.203 \\
(0.146)\end{array}$ & $\begin{array}{c}0.001 \\
(0.009)\end{array}$ & $\begin{array}{c}0.008 \\
(0.006)\end{array}$ & $\begin{array}{l}-0.475 \\
(0.373)\end{array}$ & $\begin{array}{l}-0.093^{*} \\
(0.054)\end{array}$ & $\begin{array}{c}0.081 \\
(0.076)\end{array}$ & $\begin{array}{c}-0.009^{* * * *} \\
(0.003)\end{array}$ & \\
\hline $\mathrm{x}$ & & $\begin{array}{l}-8.999^{*} \\
(4.719)\end{array}$ & $\begin{array}{c}0.025 \\
(0.033)\end{array}$ & $\begin{array}{c}2.978 \\
(1.870)\end{array}$ & $\begin{array}{c}0.131 \\
(0.102)\end{array}$ & $\begin{array}{l}-0.309 \\
(0.251)\end{array}$ & $\begin{array}{l}7.720 \\
(5.596)\end{array}$ & $\begin{array}{c}0.519 \\
(0.877)\end{array}$ & $\begin{array}{c}-4.315^{* *} \\
(1.874)\end{array}$ & $\begin{array}{c}0.020 \\
(0.034)\end{array}$ & \\
\hline Observations & 2,260 & 2,260 & 2,194 & 1,949 & 1,965 & 1,796 & 1,200 & 2,260 & 1,925 & 2,207 & 2,260 \\
\hline Countries & 38 & 38 & 38 & 35 & 35 & 34 & 20 & 38 & 31 & 38 & 38 \\
\hline$F$-statistic & 5.8 & 10.5 & 2.7 & 9.8 & 29.9 & 19.8 & 0.7 & 24.3 & 18.2 & 10.8 & 23.4 \\
\hline
\end{tabular}

Source: Authors' calculations.

Notes: Net inflows (in percent of trend GDP) for each country are instrumented using gross inflows to other EMs (in percent of trend GDP). Results are presented in terms of net outflows. MPru is divided by 10 to ease the visualization of the coefficients. The estimations are based on a sample of EM from 2000Q1 to 2016Q4. All specifications include country fixed effects. Driscoll-Kraay standard errors are reported in parentheses. ${ }^{* * *}, * *$, and $*$ indicate statistical significance at 1,5 , and 10 percent, respectively. 
Table 4: Symmetric Dampening Effects of Macroprudential Regulation on GDP Growth

\begin{tabular}{|c|c|c|}
\hline & $\begin{array}{l}\text { Asymmetric damp- } \\
\text { ening against ln } \\
\text { VIX }\end{array}$ & \begin{tabular}{lr}
\multicolumn{2}{l}{ Asymmetric damp- } \\
ening & effects \\
against net out- \\
flows
\end{tabular} \\
\hline & $(1)$ & $(2)$ \\
\hline Lag dependent variable & $\begin{array}{c}0.070 \\
(0.047)\end{array}$ & $\begin{array}{l}0.100^{*} \\
(0.051)\end{array}$ \\
\hline Lag output gap & $\begin{array}{c}-0.396 * * * \\
(0.036)\end{array}$ & $\begin{array}{c}-0.388^{* * *} \\
(0.037)\end{array}$ \\
\hline Lag ln real GDP per capita & $\begin{array}{c}-1.676^{* *} \\
(0.738)\end{array}$ & $\begin{array}{c}-1.968^{* *} \\
(0.776)\end{array}$ \\
\hline Institutional quality & $\begin{array}{c}-0.075 \\
(0.854)\end{array}$ & $\begin{array}{l}-0.048 \\
(0.931)\end{array}$ \\
\hline Linear trend & $\begin{array}{c}0.005 \\
(0.007)\end{array}$ & $\begin{array}{c}0.008 \\
(0.007)\end{array}$ \\
\hline Commodity terms of trade & $\begin{array}{c}0.035 \\
(0.054)\end{array}$ & $\begin{array}{c}0.033 \\
(0.077)\end{array}$ \\
\hline US monetary policy shock & $\begin{array}{c}0.069 \\
(0.251)\end{array}$ & $\begin{array}{c}0.082 \\
(0.314)\end{array}$ \\
\hline Ln VIX & & $\begin{array}{c}-1.555^{* * *} \\
(0.329)\end{array}$ \\
\hline Net outflows & $\begin{array}{c}-0.420^{* * *} \\
(0.106)\end{array}$ & \\
\hline US monetary policy shock * MPru & $\begin{array}{c}-0.117 \\
(0.101)\end{array}$ & $\begin{array}{c}-0.132 \\
(0.122)\end{array}$ \\
\hline Ln VIX * MPru & & $\begin{array}{c}0.634^{* * *} \\
(0.158)\end{array}$ \\
\hline Net outflows * MPru & $\begin{array}{c}0.114^{* * *} \\
(0.035)\end{array}$ & \\
\hline Mpru * D+ & $\begin{array}{c}-1.101^{* *} \\
(0.491)\end{array}$ & $\begin{array}{c}-1.324^{* * *} \\
(0.466)\end{array}$ \\
\hline Mpru * D- & $\begin{array}{c}-1.721^{* * *} \\
(0.606)\end{array}$ & $\begin{array}{c}-1.346^{* * *} \\
(0.436)\end{array}$ \\
\hline Ln VIX * D+ & $\begin{array}{c}-1.080^{* *} \\
(0.475)\end{array}$ & \\
\hline Ln VIX * D- & $\begin{array}{c}-2.139^{* * *} \\
(0.461)\end{array}$ & \\
\hline Ln VIX $*$ D $+*$ MPru & $\begin{array}{c}0.535^{* * *} \\
(0.164)\end{array}$ & \\
\hline Ln VIX * D- * MPru & $\begin{array}{c}0.751^{* * *} \\
(0.225)\end{array}$ & \\
\hline Net outflows * D+ & & $\begin{array}{c}-0.456^{* * *} \\
(0.142)\end{array}$ \\
\hline Net outflows * D- & & $\begin{array}{c}-0.478^{* * *} \\
(0.163)\end{array}$ \\
\hline Net outflows $* \mathrm{D}+{ }^{*}$ MPru & & $\begin{array}{c}0.126^{* *} \\
(0.051)\end{array}$ \\
\hline Net outflows * D- * MPru & & $\begin{array}{c}0.132^{\text {** }} \\
(0.055)\end{array}$ \\
\hline Observations & 2,260 & 2,260 \\
\hline Countries & 38 & 38 \\
\hline$F$-statistic & 27.3 & 6.9 \\
\hline Wald test ( $p$-value) & 0.421 & 0.943 \\
\hline
\end{tabular}

Source: Authors' calculations.

Notes: Net inflows (in percent of trend GDP) for each country are instrumented using gross inflows to other EMs (in percent of trend GDP). Results are presented in terms of net outflows. MPru is divided by 10 to ease the visualization of the coefficients. The estimations are based on a sample of EM from 2000Q1 to 2016Q4. All specifications include country fixed effects. DriscollKraay standard errors are reported in parentheses. ***, **, and * indicate statistical significance at 1,5 , and 10 percent, respectively. The Wald test is for the equality between the coefficient on $\left(\mathrm{S} * \mathrm{D}+{ }^{*} \mathrm{MPru}\right)$ and the one on $(\mathrm{S}$ * D- * MPru).

\section{CInternational Monetary Fund. Not for Redistribution}


Table 5: Dampening Effects of Macroprudential Categories on GDP Growth

\begin{tabular}{|c|c|c|c|c|c|}
\hline & $\begin{array}{l}\text { Mpru } \\
\text { capital }\end{array}$ & $\begin{array}{l}\text { Mpru = } \\
\text { credit } \\
\text { demand }\end{array}$ & $\begin{array}{l}\text { Mpru } \\
\text { credit } \\
\text { supply }\end{array}$ & $\begin{array}{l}\text { Mpru = FX } \\
\text { exposure }\end{array}$ & $\begin{array}{l}\text { Mpru = liq- } \\
\text { uidity }\end{array}$ \\
\hline & (1) & (2) & (3) & (4) & (5) \\
\hline Lag dependent variable & $\begin{array}{c}0.061 \\
(0.054)\end{array}$ & $\begin{array}{c}0.067 \\
(0.053)\end{array}$ & $\begin{array}{c}0.067 \\
(0.055)\end{array}$ & $\begin{array}{c}0.066 \\
(0.055)\end{array}$ & $\begin{array}{c}0.071 \\
(0.054)\end{array}$ \\
\hline Lag output gap & $\begin{array}{c}-0.374^{* * *} \\
(0.039)\end{array}$ & $\begin{array}{c}-0.381^{* * *} \\
(0.036)\end{array}$ & $\begin{array}{c}-0.374^{* * *} \\
(0.035)\end{array}$ & $\begin{array}{c}-0.383^{* * *} \\
(0.036)\end{array}$ & $\begin{array}{c}-0.372^{* * * *} \\
(0.035)\end{array}$ \\
\hline Lag ln real GDP per capita & $\begin{array}{c}-2.012^{* *} \\
(0.972)\end{array}$ & $\begin{array}{l}-0.773 \\
(0.594)\end{array}$ & $\begin{array}{c}-0.936 \\
(0.584)\end{array}$ & $\begin{array}{c}-0.682 \\
(0.531)\end{array}$ & $\begin{array}{c}-1.193^{*} \\
(0.627)\end{array}$ \\
\hline Institutional quality & $\begin{array}{c}1.456 \\
(1.439)\end{array}$ & $\begin{array}{c}0.039 \\
(0.733)\end{array}$ & $\begin{array}{l}-0.207 \\
(0.688)\end{array}$ & $\begin{array}{l}-0.417 \\
(0.661)\end{array}$ & $\begin{array}{l}-0.300 \\
(0.677)\end{array}$ \\
\hline Linear trend & $\begin{array}{c}0.009 \\
(0.010)\end{array}$ & $\begin{array}{l}-0.001 \\
(0.006)\end{array}$ & $\begin{array}{c}0.002 \\
(0.006)\end{array}$ & $\begin{array}{l}-0.000 \\
(0.005)\end{array}$ & $\begin{array}{c}0.003 \\
(0.006)\end{array}$ \\
\hline Commodity terms of trade & $\begin{array}{c}0.058 \\
(0.079)\end{array}$ & $\begin{array}{c}0.049 \\
(0.047)\end{array}$ & $\begin{array}{c}0.046 \\
(0.046)\end{array}$ & $\begin{array}{c}0.049 \\
(0.038)\end{array}$ & $\begin{array}{c}0.052 \\
(0.037)\end{array}$ \\
\hline US monetary policy shock & $\begin{array}{l}-0.059 \\
(0.194)\end{array}$ & $\begin{array}{l}-0.155 \\
(0.168)\end{array}$ & $\begin{array}{c}-0.146 \\
(0.172)\end{array}$ & $\begin{array}{l}-0.162 \\
(0.174)\end{array}$ & $\begin{array}{c}-0.160 \\
(0.173)\end{array}$ \\
\hline Ln VIX & $\begin{array}{l}-0.524 \\
(0.435)\end{array}$ & $\begin{array}{c}-0.741^{* * *} \\
(0.193)\end{array}$ & $\begin{array}{c}-0.672^{* * *} \\
(0.197)\end{array}$ & $\begin{array}{c}-0.777^{* * *} \\
(0.179)\end{array}$ & $\begin{array}{c}-0.766^{* * *} \\
(0.196)\end{array}$ \\
\hline Net outflows & $\begin{array}{c}-0.495^{* * *} \\
(0.177)\end{array}$ & $\begin{array}{c}-0.247^{* * *} \\
(0.064)\end{array}$ & $\begin{array}{c}-0.223^{* * *} \\
(0.059)\end{array}$ & $\begin{array}{c}-0.199^{* * *} \\
(0.049)\end{array}$ & $\begin{array}{c}-0.205^{* * * *} \\
(0.053)\end{array}$ \\
\hline Mpru & $\begin{array}{c}8.040 \\
(12.012)\end{array}$ & $\begin{array}{l}-3.021 \\
(2.376)\end{array}$ & $\begin{array}{c}0.886 \\
(5.846)\end{array}$ & $\begin{array}{c}-10.270^{* * *} \\
(2.420)\end{array}$ & $\begin{array}{c}-2.044^{* *} \\
(0.887)\end{array}$ \\
\hline US monetary policy shock * Mpru & $\begin{array}{l}-1.106 \\
(1.190)\end{array}$ & $\begin{array}{l}-0.245 \\
(0.422)\end{array}$ & $\begin{array}{l}-0.349 \\
(0.855)\end{array}$ & $\begin{array}{c}0.169 \\
(0.646)\end{array}$ & $\begin{array}{c}0.067 \\
(0.136)\end{array}$ \\
\hline Ln VIX * Mpru & $\begin{array}{l}-1.119 \\
(4.752)\end{array}$ & $\begin{array}{c}1.663^{*} \\
(0.866)\end{array}$ & $\begin{array}{c}0.806 \\
(1.918)\end{array}$ & $\begin{array}{c}3.324^{* * * *} \\
(0.756)\end{array}$ & $\begin{array}{c}0.846^{* * *} \\
(0.248)\end{array}$ \\
\hline Net outflows * Mpru & $\begin{array}{c}2.390^{* *} \\
(1.129)\end{array}$ & $\begin{array}{c}0.638^{* * *} * \\
(0.223)\end{array}$ & $\begin{array}{c}0.709^{* *} \\
(0.300)\end{array}$ & $\begin{array}{l}-0.115 \\
(0.128)\end{array}$ & $\begin{array}{c}0.062 \\
(0.072)\end{array}$ \\
\hline $\mathrm{MPru}^{2}$ & $\begin{array}{l}-19.297 \\
(19.623)\end{array}$ & $\begin{array}{c}2.019 \\
(2.647)\end{array}$ & $\begin{array}{l}-2.833 \\
(6.464)\end{array}$ & $\begin{array}{c}10.829^{* * *} \\
(2.698)\end{array}$ & $\begin{array}{c}0.315 \\
(0.434)\end{array}$ \\
\hline US monetary policy shock $* \mathrm{MPru}^{2}$ & $\begin{array}{c}0.501 \\
(2.061)\end{array}$ & $\begin{array}{c}0.390 \\
(0.356)\end{array}$ & $\begin{array}{c}0.245 \\
(0.858)\end{array}$ & $\begin{array}{c}0.017 \\
(0.743)\end{array}$ & $\begin{array}{l}-0.054 \\
(0.078)\end{array}$ \\
\hline Ln VIX $* \mathrm{MPru}^{2}$ & $\begin{array}{c}5.784 \\
(7.565)\end{array}$ & $\begin{array}{l}-1.179 \\
(1.005)\end{array}$ & $\begin{array}{c}0.073 \\
(2.201)\end{array}$ & $\begin{array}{c}-3.068^{* * *} \\
(0.844)\end{array}$ & $\begin{array}{l}-0.127 \\
(0.146)\end{array}$ \\
\hline Net outflows * MPru ${ }^{2}$ & $\begin{array}{c}-3.214^{* *} \\
(1.624)\end{array}$ & $\begin{array}{c}-0.426^{* * *} \\
(0.163)\end{array}$ & $\begin{array}{l}-0.886 \\
(5.846)\end{array}$ & $\begin{array}{c}0.318^{* *} \\
(0.145)\end{array}$ & $\begin{array}{c}0.015 \\
(0.042)\end{array}$ \\
\hline Observations & 2,260 & 2,260 & 2,260 & 2,260 & 2,260 \\
\hline Countries & 38 & 38 & 38 & 38 & 38 \\
\hline$F$-statistic & 4.0 & 14.2 & 12.7 & 22.9 & 12.4 \\
\hline
\end{tabular}

Source: Authors' calculations.

Notes: Net inflows (in percent of trend GDP) for each country are instrumented using gross inflows to other EMs (in percent of trend GDP). Results are presented in terms of net outflows. MPru is divided by 10 to ease the visualization of the coefficients. The estimations are based on a sample of EM from 2000Q1 to 2016Q4. All specifications include country fixed effects. Driscoll-Kraay standard errors are reported in parentheses. ${ }^{* * *},{ }^{* *}$, and ${ }^{*}$ indicate statistical significance at 1,5 , and 10 percent, respectively. 
Table 6: Regressions of Real GDP Growth, Spillovers

\begin{tabular}{|c|c|c|c|c|c|c|}
\hline & $\begin{array}{l}\text { Others' } \\
\text { MPru = } \\
\text { EMs' aver- } \\
\text { age }\end{array}$ & $\begin{array}{l}\text { Others' MPru } \\
=\quad \text { average } \\
\text { across EMs } \\
\text { in the same } \\
\text { region }\end{array}$ & $\begin{array}{l}\text { Others' MPru } \\
=\quad \text { average } \\
\text { across } \\
\text { in the same } \\
\text { income class } \\
\text { (time varying) }\end{array}$ & $\begin{array}{l}\text { Others' MPru } \\
=\text { average } \\
\text { across EMs } \\
\text { in the same } \\
\text { income class } \\
\text { (time invari- } \\
\text { ant) }\end{array}$ & $\begin{array}{l}\text { Others' MPru } \\
=\quad \text { average } \\
\text { across EMs in } \\
\text { the same risk } \\
\text { class (time } \\
\text { varying) }\end{array}$ & $\begin{array}{l}\text { Others' MPru } \\
=\text { average } \\
\text { across EMs in } \\
\text { the same risk } \\
\text { class (time } \\
\text { invariant) }\end{array}$ \\
\hline & $(1)$ & $(2)$ & $(3)$ & $(4)$ & $(5)$ & $(6)$ \\
\hline Lag dependent variable & $\begin{array}{c}0.024 \\
(0.055)\end{array}$ & $\begin{array}{c}0.070 \\
(0.050)\end{array}$ & $\begin{array}{c}0.071 \\
(0.048)\end{array}$ & $\begin{array}{c}0.055 \\
(0.048)\end{array}$ & $\begin{array}{c}0.067 \\
(0.055)\end{array}$ & $\begin{array}{c}0.052 \\
(0.047)\end{array}$ \\
\hline Lag output gap & $\begin{array}{c}-0.382^{* * *} \\
(0.046)\end{array}$ & $\begin{array}{c}-0.381^{* * *} \\
(0.037)\end{array}$ & $\begin{array}{c}-0.381^{* * *} \\
(0.039)\end{array}$ & $\begin{array}{c}-0.360^{* * *} \\
(0.034)\end{array}$ & $\begin{array}{c}-0.339^{* * *} \\
(0.031)\end{array}$ & $\begin{array}{c}-0.359^{* * *} \\
(0.032)\end{array}$ \\
\hline Lag ln real GDP per capita & $\begin{array}{c}-1.448 \\
(1.235)\end{array}$ & $\begin{array}{c}-1.579^{* *} \\
(0.723)\end{array}$ & $\begin{array}{c}-0.992 \\
(0.779)\end{array}$ & $\begin{array}{c}-1.763^{* *} \\
(0.728)\end{array}$ & $\begin{array}{c}-3.431^{* * *} \\
(1.038)\end{array}$ & $\begin{array}{c}-1.568^{* *} \\
(0.771)\end{array}$ \\
\hline Institutional quality & $\begin{array}{c}2.967 \\
(1.911)\end{array}$ & $\begin{array}{c}0.416 \\
(0.865)\end{array}$ & $\begin{array}{c}0.950 \\
(1.083)\end{array}$ & $\begin{array}{c}0.394 \\
(0.884)\end{array}$ & $\begin{array}{c}2.327^{*} \\
(1.203)\end{array}$ & $\begin{array}{c}0.865 \\
(0.883)\end{array}$ \\
\hline Linear trend & $\begin{array}{c}-0.089^{*} \\
(0.047)\end{array}$ & $\begin{array}{c}0.008 \\
(0.008)\end{array}$ & $\begin{array}{l}-0.003 \\
(0.008)\end{array}$ & $\begin{array}{c}0.011 \\
(0.009)\end{array}$ & $\begin{array}{l}-0.011 \\
(0.008)\end{array}$ & $\begin{array}{l}-0.009 \\
(0.009)\end{array}$ \\
\hline Commodity terms of trade & $\begin{array}{c}0.089 \\
(0.097)\end{array}$ & $\begin{array}{c}0.063 \\
(0.051)\end{array}$ & $\begin{array}{c}0.024 \\
(0.063)\end{array}$ & $\begin{array}{c}0.022 \\
(0.050)\end{array}$ & $\begin{array}{c}0.063 \\
(0.063)\end{array}$ & $\begin{array}{c}0.067 \\
(0.050)\end{array}$ \\
\hline US monetary policy shock & $\begin{array}{c}0.137 \\
(0.699)\end{array}$ & $\begin{array}{c}0.028 \\
(0.349)\end{array}$ & $\begin{array}{l}-0.173 \\
(0.475)\end{array}$ & $\begin{array}{l}-0.253 \\
(0.448)\end{array}$ & $\begin{array}{c}0.008 \\
(0.387)\end{array}$ & $\begin{array}{c}-0.058 \\
(0.331)\end{array}$ \\
\hline Ln VIX & $\begin{array}{c}-1.469^{*} \\
(0.794)\end{array}$ & $\begin{array}{c}-1.748^{* * *} \\
(0.472)\end{array}$ & $\begin{array}{c}-1.236^{* *} \\
(0.579)\end{array}$ & $\begin{array}{c}-1.498^{* * *} \\
(0.471)\end{array}$ & $\begin{array}{c}-1.817^{* * *} \\
(0.484)\end{array}$ & $\begin{array}{c}-1.669^{* * *} \\
(0.458)\end{array}$ \\
\hline Net outflows & $\begin{array}{c}-1.367^{* * * *} \\
(0.479)\end{array}$ & $\begin{array}{c}-0.600^{* * *} \\
(0.153)\end{array}$ & $\begin{array}{c}-0.683^{* * *} \\
(0.226)\end{array}$ & $\begin{array}{c}-0.535^{* * *} \\
(0.168)\end{array}$ & $\begin{array}{c}-0.828^{* * * *} \\
(0.225)\end{array}$ & $\begin{array}{c}-0.626^{* * *} \\
(0.152)\end{array}$ \\
\hline MPru & $\begin{array}{c}-2.864^{* * *} \\
(0.932)\end{array}$ & $\begin{array}{c}-1.582^{* * *} \\
(0.459)\end{array}$ & $\begin{array}{c}-1.855^{* * *} \\
(0.556)\end{array}$ & $\begin{array}{c}-1.429^{* * *} \\
(0.456)\end{array}$ & $\begin{array}{c}-1.479^{* * *} \\
(0.463)\end{array}$ & $\begin{array}{c}-1.630^{* * *} \\
(0.453)\end{array}$ \\
\hline US monetary policy shock * MPru & $\begin{array}{l}-0.166 \\
(0.145)\end{array}$ & $\begin{array}{l}-0.105 \\
(0.120)\end{array}$ & $\begin{array}{c}-0.097 \\
(0.136)\end{array}$ & $\begin{array}{c}-0.088 \\
(0.125)\end{array}$ & $\begin{array}{c}-0.109 \\
(0.116)\end{array}$ & $\begin{array}{c}-0.084 \\
(0.100)\end{array}$ \\
\hline Ln VIX * MPru & $\begin{array}{c}1.207^{* * *} \\
(0.374)\end{array}$ & $\begin{array}{c}0.709^{* * *} \\
(0.168)\end{array}$ & $\begin{array}{c}0.731^{* * *} \\
(0.197)\end{array}$ & $\begin{array}{c}0.635^{* * *} \\
(0.165)\end{array}$ & $\begin{array}{c}0.747^{* * *} \\
(0.178)\end{array}$ & $\begin{array}{c}0.692^{* * *} \\
(0.165)\end{array}$ \\
\hline Net outflows $*$ MPru & $\begin{array}{c}0.148^{* * *} \\
(0.054)\end{array}$ & $\begin{array}{c}0.120^{* * *} \\
(0.040)\end{array}$ & $\begin{array}{c}0.138^{* * *} \\
(0.053)\end{array}$ & $\begin{array}{c}0.121^{* * *} \\
(0.044)\end{array}$ & $\begin{array}{c}0.145^{* * *} \\
(0.049)\end{array}$ & $\begin{array}{c}0.105^{* * *} \\
(0.034)\end{array}$ \\
\hline US monetary policy shock * others' MPru & $\begin{array}{c}0.005 \\
(0.195)\end{array}$ & $\begin{array}{l}-0.025 \\
(0.070)\end{array}$ & $\begin{array}{c}0.059 \\
(0.075)\end{array}$ & $\begin{array}{c}0.077 \\
(0.061)\end{array}$ & $\begin{array}{l}-0.021 \\
(0.102)\end{array}$ & $\begin{array}{c}0.004 \\
(0.069)\end{array}$ \\
\hline Ln VIX * others' MPru & $\begin{array}{c}-0.515 \\
(0.435)\end{array}$ & $\begin{array}{c}0.031 \\
(0.131)\end{array}$ & $\begin{array}{l}-0.149 \\
(0.189)\end{array}$ & $\begin{array}{c}-0.004 \\
(0.139)\end{array}$ & $\begin{array}{c}0.130 \\
(0.144)\end{array}$ & $\begin{array}{c}0.034 \\
(0.104)\end{array}$ \\
\hline Net outflows * others' MPru & $\begin{array}{c}0.418^{* *} \\
(0.175)\end{array}$ & $\begin{array}{c}0.120^{* * *} \\
(0.031)\end{array}$ & $\begin{array}{c}0.113^{* *} \\
(0.044)\end{array}$ & $\begin{array}{c}0.068^{* *} \\
(0.031)\end{array}$ & $\begin{array}{c}0.170^{* * *} \\
(0.050)\end{array}$ & $\begin{array}{c}0.116^{* * *} \\
(0.032)\end{array}$ \\
\hline Others' MPru & $\begin{array}{l}4.296^{*} \\
(2.388)\end{array}$ & $\begin{array}{l}-0.027 \\
(0.367)\end{array}$ & $\begin{array}{c}0.863 \\
(0.682)\end{array}$ & $\begin{array}{c}0.148 \\
(0.433)\end{array}$ & $\begin{array}{c}0.486 \\
(0.480)\end{array}$ & $\begin{array}{c}0.469 \\
(0.336)\end{array}$ \\
\hline Observations & 2,260 & 2,192 & 2,260 & 2,260 & 2,108 & 2,260 \\
\hline Countries & 38 & 37 & 38 & 38 & 35 & 38 \\
\hline$F$-statistic & 4.1 & 19.6 & 9.4 & 6.4 & 10.8 & 20.7 \\
\hline Wald test ( $p$-value) & 0.063 & 0.993 & 0.384 & 0.078 & 0.511 & 0.739 \\
\hline
\end{tabular}

Source: Authors' calculations.

Notes: Net inflows (in percent of trend GDP) for each country are instrumented using gross inflows to other EMs (in percent of trend GDP). Results are presented in terms of net outflows. MPru is divided by 10 to ease the visualization of the coefficients. The estimations are based on a sample of EM from 2000Q1 to 2016Q4. All specifications include country fixed effects. Driscoll-Kraay standard errors are reported in parentheses. ${ }^{* *},{ }^{* *}$, and ${ }^{*}$ indicate statistical significance at 1,5 , and 10 percent, respectively. The Wald test is for the equality between the coefficient on (net outflows * MPru) and the one on (net outflows * others' MPru). 
Table 7: Regressions of Domestic Policy Rates, Baseline Results

\begin{tabular}{|c|c|c|c|c|c|}
\hline & $(1)$ & $(2)$ & (3) & $(4)$ & $(5)$ \\
\hline US policy rate & $\begin{array}{c}0.597^{* * *} \\
(0.068)\end{array}$ & $\begin{array}{c}0.359^{* * *} * \\
(0.034)\end{array}$ & $\begin{array}{c}0.295^{* * *} \\
(0.037)\end{array}$ & & $\begin{array}{c}0.366^{* * *} \\
(0.066)\end{array}$ \\
\hline Ln VIX & $\begin{array}{c}1.396 * * * \\
(0.482)\end{array}$ & $\begin{array}{c}0.587^{* *} \\
(0.283)\end{array}$ & $\begin{array}{c}0.599^{* *} \\
(0.302)\end{array}$ & $\begin{array}{c}0.732^{* *} \\
(0.304)\end{array}$ & $\begin{array}{c}2.098^{* * *} \\
(0.451)\end{array}$ \\
\hline Net outflows & $\begin{array}{c}0.404^{* * *} \\
(0.118)\end{array}$ & $\begin{array}{c}0.347^{* * *} \\
(0.079)\end{array}$ & $\begin{array}{c}0.337^{* * *} \\
(0.084)\end{array}$ & $\begin{array}{c}0.169 \\
(0.123)\end{array}$ & $\begin{array}{c}0.418^{* * *} \\
(0.127)\end{array}$ \\
\hline Expected inflation, next 12 months & & $\begin{array}{c}1.235^{* * *} \\
(0.075)\end{array}$ & $\begin{array}{c}1.224^{* * *} \\
(0.077)\end{array}$ & $\begin{array}{c}1.251^{* * *} \\
(0.079)\end{array}$ & $\begin{array}{c}1.227^{* * *} * \\
(0.075)\end{array}$ \\
\hline Output gap & & $\begin{array}{c}0.250^{* * *} \\
(0.082)\end{array}$ & $\begin{array}{c}0.148^{* *} \\
(0.066)\end{array}$ & $\begin{array}{c}0.151^{* *} \\
(0.070)\end{array}$ & $\begin{array}{c}0.208^{* * *} \\
(0.071)\end{array}$ \\
\hline Real credit growth & & & $\begin{array}{c}0.050^{* * *} * \\
(0.014)\end{array}$ & $\begin{array}{c}0.047^{* * *} * \\
(0.016)\end{array}$ & $\begin{array}{c}0.050^{* * *} \\
(0.014)\end{array}$ \\
\hline Commodity terms of trade & & & $\begin{array}{c}-0.085^{* *} \\
(0.042)\end{array}$ & $\begin{array}{c}-0.113^{* * *} \\
(0.038)\end{array}$ & $\begin{array}{c}-0.102^{* *} \\
(0.044)\end{array}$ \\
\hline US policy shock & & & & $\begin{array}{l}-0.061 \\
(0.157)\end{array}$ & \\
\hline MPru & & & & & $\begin{array}{c}0.220^{* * *} \\
(0.053)\end{array}$ \\
\hline US policy rate ${ }^{*}$ MPru & & & & & $\begin{array}{c}-0.013^{* * *} \\
(0.004)\end{array}$ \\
\hline Ln VIX * MPru & & & & & $\begin{array}{c}-0.116^{* * *} \\
(0.020)\end{array}$ \\
\hline Net outflows * MPru & & & & & $\begin{array}{l}-0.004 \\
(0.004)\end{array}$ \\
\hline Observations & 1360 & 1262 & 1250 & 1250 & 1250 \\
\hline Country FE & Yes & Yes & Yes & Yes & Yes \\
\hline F-statistic & 73.98 & 56.42 & 49.70 & 26.32 & 21.98 \\
\hline
\end{tabular}

Source: Authors' calculations.

Notes: Net inflows (in percent of trend GDP) for each country are instrumented using gross inflows to other EMs (in percent of trend GDP). Results are presented in terms of net outflows. The US policy rate is the effective federal funds rate except during the zero lower bound period where the implied policy rate from $\mathrm{Wu}$ and Xia (2015) is used. The estimations are done using fixed effects on a panel of EMs, excluding countries with pegged and freely falling exchange rates (Ilzetzki et al., 2019), during 2000Q1 to 2016Q4. Driscoll-Kraay standard errors are reported in parenthesis. ${ }^{* * *}, * *$, and $*$ indicate statistical significance on 1,5 , and 10 , percent level, respectively. 
Table 8: Regressions of Domestic Policy Rates: Robustness to Reverse Causality

\begin{tabular}{|c|c|c|c|}
\hline & $\begin{array}{l}\text { MPru }= \\
\text { one-quarter } \\
\text { lag of MPru }\end{array}$ & $\begin{array}{ll}\text { MPru } & = \\
\text { one-year } & \\
\text { lag of } \\
\text { MPru }\end{array}$ & $\begin{array}{l}\text { MPru = } \\
\text { country } \\
\text { average of } \\
\text { MPru }\end{array}$ \\
\hline & (1) & $(2)$ & $(3)$ \\
\hline US policy rate & $\begin{array}{c}0.366^{* * *} \\
(0.065)\end{array}$ & $\begin{array}{c}0.409^{* * *} \\
(0.067)\end{array}$ & $\begin{array}{c}0.351^{* * *} \\
(0.063)\end{array}$ \\
\hline Ln VIX & $\begin{array}{c}2.120^{* * *} * \\
(0.452)\end{array}$ & $\begin{array}{c}2.175^{* * *} \\
(0.480)\end{array}$ & $\begin{array}{c}2.407^{* * *} * \\
(0.402)\end{array}$ \\
\hline Net outflows & $\begin{array}{c}0.406^{* * *} \\
(0.126)\end{array}$ & $\begin{array}{c}0.391^{* * *} \\
(0.130)\end{array}$ & $\begin{array}{c}0.566^{* * *} \\
(0.182)\end{array}$ \\
\hline Expected inflation, next 12 months & $\begin{array}{c}1.207^{* * *} \\
(0.075)\end{array}$ & $\begin{array}{c}1.186^{* * *} \\
(0.080)\end{array}$ & $\begin{array}{c}1.238^{* * *} \\
(0.079)\end{array}$ \\
\hline Output gap & $\begin{array}{c}0.204^{* * *} \\
(0.071)\end{array}$ & $\begin{array}{c}0.160^{* *} \\
(0.071)\end{array}$ & $\begin{array}{c}0.157^{* *} \\
(0.069)\end{array}$ \\
\hline Real credit growth & $\begin{array}{c}0.052^{* * *} \\
(0.014)\end{array}$ & $\begin{array}{c}0.052^{* * *} \\
(0.015)\end{array}$ & $\begin{array}{c}0.052^{* * *} \\
(0.015)\end{array}$ \\
\hline Commodity terms of trade & $\begin{array}{c}-0.102^{* *} \\
(0.045)\end{array}$ & $\begin{array}{c}-0.091^{* *} \\
(0.046)\end{array}$ & $\begin{array}{c}-0.084^{* *} \\
(0.042)\end{array}$ \\
\hline MPru & $\begin{array}{c}0.217^{* * *} * \\
(0.055)\end{array}$ & $\begin{array}{c}0.242^{* * *} \\
(0.061)\end{array}$ & \\
\hline US policy rate ${ }^{*}$ MPru & $\begin{array}{c}-0.014^{* * *} \\
(0.004)\end{array}$ & $\begin{array}{c}-0.018^{* * *} \\
(0.004)\end{array}$ & $\begin{array}{l}-0.005 \\
(0.003)\end{array}$ \\
\hline Ln VIX * MPru & $\begin{array}{c}-0.116^{* * *} \\
(0.021)\end{array}$ & $\begin{array}{c}-0.129^{* * *} \\
(0.025)\end{array}$ & $\begin{array}{c}-0.124^{* * *} \\
(0.021)\end{array}$ \\
\hline Net outflows $*$ MPru & $\begin{array}{l}-0.003 \\
(0.004)\end{array}$ & $\begin{array}{l}-0.001 \\
(0.004)\end{array}$ & $\begin{array}{c}-0.014^{* *} \\
(0.007)\end{array}$ \\
\hline Observations & 1241 & 1211 & 1250 \\
\hline Countries & 25 & 25 & 25 \\
\hline$F$-statistic & 22.97 & 22.15 & 20.53 \\
\hline
\end{tabular}

Source: Authors' calculations.

Notes: Net inflows (in percent of trend GDP) for each country are instrumented using gross inflows to other EMs (in percent of trend GDP). Results are presented in terms of net outflows. The US policy rate is the effective federal funds rate except during the zero lower bound period where the implied policy rate from $\mathrm{Wu}$ and Xia (2015) is used. The estimations are done using fixed effects on a panel of EMs, excluding countries with pegged and freely falling exchange rates (Ilzetzki et al., 2019), during 2000Q1 to 2016Q4. Driscoll-Kraay standard errors are reported in parenthesis. ${ }^{* * *}, * *$, and $*$ indicate statistical significance on 1,5 , and 10 , percent level, respectively.

\section{CInternational Monetary Fund. Not for Redistribution}


Table 9: Regressions of Domestic Policy Rates: Robustness to Omitted Variables

\begin{tabular}{|c|c|c|c|c|c|c|c|c|c|}
\hline & $\begin{array}{l}\mathrm{X}=\text { in- } \\
\text { stitutional } \\
\text { quality }\end{array}$ & $\begin{array}{l}\mathrm{X}=\text { finan- } \\
\text { cial develop- } \\
\text { ment }\end{array}$ & $\begin{array}{l}\mathrm{X}=\text { gross } \\
\text { public debt }\end{array}$ & $\begin{array}{l}\mathrm{X}=\text { gov- } \\
\text { ernment } \\
\text { FX debt }\end{array}$ & $\begin{array}{l}X=\text { cycli- } \\
\text { cal ad- } \\
\text { justed } \\
\text { balance }\end{array}$ & $\begin{array}{l}\mathrm{X}=\text { in- } \\
\text { flation } \\
\text { expectation } \\
\text { anchoring }\end{array}$ & $\begin{array}{l}\mathrm{X}=\text { cap- } \\
\text { ital flow } \\
\text { measures }\end{array}$ & $\begin{array}{l}X=\text { of- } \\
\text { ficial re- } \\
\text { serves }\end{array}$ & $\begin{array}{l}\text { Including } \\
\text { time } \\
\text { fixed } \\
\text { effects }\end{array}$ \\
\hline & (1) & $(2)$ & $(3)$ & (4) & $(5)$ & $(6)$ & (7) & $(8)$ & (9) \\
\hline US policy rate & $\begin{array}{c}0.347^{* * *} \\
(0.073)\end{array}$ & $\begin{array}{c}0.053 \\
(0.136)\end{array}$ & $\begin{array}{l}-0.061 \\
(0.128)\end{array}$ & $\begin{array}{c}0.583^{* * *} \\
(0.090)\end{array}$ & $\begin{array}{c}0.566^{* * * *} \\
(0.079)\end{array}$ & $\begin{array}{c}0.235^{* * *} \\
(0.070)\end{array}$ & $\begin{array}{c}0.315^{* * *} \\
(0.089)\end{array}$ & $\begin{array}{c}0.324^{* * *} * \\
(0.097)\end{array}$ & $\begin{array}{c}2.899^{* * *} * \\
(0.428)\end{array}$ \\
\hline Ln VIX & $\begin{array}{c}1.941^{* * *} \\
(0.486)\end{array}$ & $\begin{array}{c}2.757^{* * *} \\
(0.699)\end{array}$ & $\begin{array}{c}0.187 \\
(0.963)\end{array}$ & $\begin{array}{c}1.260^{* *} \\
(0.540)\end{array}$ & $\begin{array}{c}1.960^{* * *} \\
(0.376)\end{array}$ & $\begin{array}{c}1.884^{* * *} \\
(0.401)\end{array}$ & $\begin{array}{c}1.490^{* * *} \\
(0.434)\end{array}$ & $\begin{array}{c}1.637^{* * *} \\
(0.435)\end{array}$ & $\begin{array}{c}0.643^{* *} \\
(0.312)\end{array}$ \\
\hline Net outflows & $\begin{array}{c}0.415^{* * *} \\
(0.123)\end{array}$ & $\begin{array}{c}0.178 \\
(0.168)\end{array}$ & $\begin{array}{c}0.347^{*} \\
(0.187)\end{array}$ & $\begin{array}{c}0.591^{* * *} \\
(0.142)\end{array}$ & $\begin{array}{c}0.331^{* * *} \\
(0.100)\end{array}$ & $\begin{array}{c}0.146 \\
(0.185)\end{array}$ & $\begin{array}{c}0.221^{* * *} \\
(0.081)\end{array}$ & $\begin{array}{c}0.591^{* * *} \\
(0.174)\end{array}$ & $\begin{array}{c}0.076 \\
(0.047)\end{array}$ \\
\hline Expected inflation, next 12 months & $\begin{array}{c}1.218^{* * *} \\
(0.077)\end{array}$ & $\begin{array}{c}1.197^{* * *} \\
(0.084)\end{array}$ & $\begin{array}{c}1.230^{* * * *} \\
(0.072)\end{array}$ & $\begin{array}{c}1.209^{* * *} \\
(0.085)\end{array}$ & $\begin{array}{c}1.182^{* * *} \\
(0.070)\end{array}$ & $\begin{array}{c}1.150^{* * *} \\
(0.097)\end{array}$ & $\begin{array}{c}1.205^{* * *} \\
(0.078)\end{array}$ & $\begin{array}{c}1.143^{* * *} \\
(0.077)\end{array}$ & $\begin{array}{c}1.161^{* * *} \\
(0.075)\end{array}$ \\
\hline Output gap & $\begin{array}{c}0.202^{* * *} \\
(0.070)\end{array}$ & $\begin{array}{c}0.189^{* * *} \\
(0.070)\end{array}$ & $\begin{array}{c}0.194^{* * *} \\
(0.066)\end{array}$ & $\begin{array}{c}0.212^{* * *} \\
(0.072)\end{array}$ & $\begin{array}{c}0.227^{* * *} \\
(0.068)\end{array}$ & $\begin{array}{l}0.170^{*} \\
(0.087)\end{array}$ & $\begin{array}{c}0.175^{* * *} \\
(0.067)\end{array}$ & $\begin{array}{c}0.162^{* * *} \\
(0.058)\end{array}$ & $\begin{array}{l}0.120^{*} \\
(0.069)\end{array}$ \\
\hline Real credit growth & $\begin{array}{c}0.048^{* * *} \\
(0.013)\end{array}$ & $\begin{array}{c}0.047^{* * *} \\
(0.012)\end{array}$ & $\begin{array}{c}0.047^{* * *} \\
(0.013)\end{array}$ & $\begin{array}{c}0.035^{* * *} \\
(0.011)\end{array}$ & $\begin{array}{c}0.049^{* * *} \\
(0.013)\end{array}$ & $\begin{array}{c}0.031 \\
(0.020)\end{array}$ & $\begin{array}{c}0.042^{* * *} \\
(0.011)\end{array}$ & $\begin{array}{c}0.050^{* * * *} \\
(0.013)\end{array}$ & $\begin{array}{c}0.034^{* * * *} \\
(0.009)\end{array}$ \\
\hline Commodity terms of trade & $\begin{array}{c}-0.104^{* *} \\
(0.047)\end{array}$ & $\begin{array}{c}-0.075 \\
(0.046)\end{array}$ & $\begin{array}{c}-0.148^{* * *} \\
(0.048)\end{array}$ & $\begin{array}{c}-0.114^{* *} \\
(0.058)\end{array}$ & $\begin{array}{c}-0.119^{* * *} \\
(0.045)\end{array}$ & $\begin{array}{l}-0.043 \\
(0.035)\end{array}$ & $\begin{array}{c}-0.082^{*} \\
(0.042)\end{array}$ & $\begin{array}{c}-0.081^{* *} \\
(0.040)\end{array}$ & $\begin{array}{c}-0.038 \\
(0.038)\end{array}$ \\
\hline MPru & $\begin{array}{c}0.201^{* * *} \\
(0.055)\end{array}$ & $\begin{array}{c}0.228^{* * *} \\
(0.042)\end{array}$ & $\begin{array}{c}0.172^{* * *} \\
(0.062)\end{array}$ & $\begin{array}{c}0.166^{* * *} \\
(0.050)\end{array}$ & $\begin{array}{c}0.148^{* * *} \\
(0.055)\end{array}$ & $\begin{array}{c}0.160 \\
(0.101)\end{array}$ & $\begin{array}{c}0.190^{* * *} \\
(0.046)\end{array}$ & $\begin{array}{c}0.164^{* * *} \\
(0.053)\end{array}$ & $\begin{array}{c}0.084^{* *} \\
(0.040)\end{array}$ \\
\hline US policy rate $*$ MPru & $\begin{array}{c}-0.012^{* * * *} \\
(0.004)\end{array}$ & $\begin{array}{c}-0.012^{* * * *} \\
(0.003)\end{array}$ & $\begin{array}{c}-0.008^{*} \\
(0.004)\end{array}$ & $\begin{array}{c}-0.017^{* * * *} \\
(0.004)\end{array}$ & $\begin{array}{c}-0.021^{* * * *} \\
(0.004)\end{array}$ & $\begin{array}{c}-0.008^{* *} \\
(0.004)\end{array}$ & $\begin{array}{c}-0.013^{* * *} \\
(0.003)\end{array}$ & $\begin{array}{c}-0.005 \\
(0.004)\end{array}$ & $\begin{array}{c}-0.016^{\text {*** }} \\
(0.002)\end{array}$ \\
\hline Ln VIX * MPru & $\begin{array}{c}-0.111^{* * *} \\
(0.021)\end{array}$ & $\begin{array}{c}-0.107^{* * * *} \\
(0.016)\end{array}$ & $\begin{array}{c}-0.097^{* * *} * \\
(0.024)\end{array}$ & $\begin{array}{c}-0.099^{* * *} \\
(0.019)\end{array}$ & $\begin{array}{c}-0.088^{* * *} \\
(0.020)\end{array}$ & $\begin{array}{c}-0.074^{* *} \\
(0.037)\end{array}$ & $\begin{array}{c}-0.104^{* * *} \\
(0.017)\end{array}$ & $\begin{array}{c}-0.091^{* * *} \\
(0.020)\end{array}$ & $\begin{array}{c}-0.064^{* * *} \\
(0.015)\end{array}$ \\
\hline Net outflows * MPru & $\begin{array}{c}-0.004 \\
(0.004) \\
(2.117)\end{array}$ & $\begin{array}{c}-0.002 \\
(0.004) \\
(6.952)\end{array}$ & $\begin{array}{c}-0.002 \\
(0.003) \\
(0.040)\end{array}$ & $\begin{array}{c}-0.005 \\
(0.003) \\
(3.402)\end{array}$ & $\begin{array}{c}-0.008^{*} \\
(0.005) \\
(0.289)\end{array}$ & $\begin{array}{c}0.001 \\
(0.004) \\
(4.867)\end{array}$ & $\begin{array}{c}-0.004 \\
(0.003) \\
(3.336)\end{array}$ & $\begin{array}{c}-0.000 \\
(0.003) \\
(0.069)\end{array}$ & $\begin{array}{c}0.001 \\
(0.002)\end{array}$ \\
\hline US policy rate ${ }^{*} \mathrm{X}$ & $\begin{array}{c}0.039 \\
(0.058)\end{array}$ & $\begin{array}{c}0.670^{* *} \\
(0.310)\end{array}$ & $\begin{array}{c}0.009^{* * *} \\
(0.002)\end{array}$ & $\begin{array}{c}-0.407^{* *} \\
(0.189)\end{array}$ & $\begin{array}{l}-0.010 \\
(0.009)\end{array}$ & $\begin{array}{l}-0.101 \\
(0.196)\end{array}$ & $\begin{array}{c}0.067 \\
(0.102)\end{array}$ & $\begin{array}{c}-0.008^{*} \\
(0.005)\end{array}$ & \\
\hline Ln VIX * X & $\begin{array}{l}0.568 \\
(0.441)\end{array}$ & $\begin{array}{c}-1.851 \\
(1.609)\end{array}$ & $\begin{array}{c}0.037^{* *} \\
(0.016)\end{array}$ & $\begin{array}{c}2.290^{* *} \\
(1.126)\end{array}$ & $\begin{array}{c}0.068 \\
(0.087)\end{array}$ & $\begin{array}{l}-1.066 \\
(1.428)\end{array}$ & $\begin{array}{c}0.478 \\
(0.966)\end{array}$ & $\begin{array}{c}0.009 \\
(0.021)\end{array}$ & \\
\hline Net outflows $* \mathrm{X}$ & $\begin{array}{l}-0.053 \\
(0.178)\end{array}$ & $\begin{array}{c}0.362 \\
(0.392)\end{array}$ & $\begin{array}{c}0.001 \\
(0.003)\end{array}$ & $\begin{array}{c}-0.525^{* *} \\
(0.235)\end{array}$ & $\begin{array}{c}-0.045^{* *} \\
(0.020)\end{array}$ & $\begin{array}{c}0.167 \\
(0.190)\end{array}$ & $\begin{array}{c}0.329^{* *} \\
(0.137)\end{array}$ & $\begin{array}{c}-0.016^{* * * *} \\
(0.005)\end{array}$ & \\
\hline $\mathrm{X}$ & 0.942 & -0.803 & $-0.144^{* * *}$ & $-6.287^{*}$ & $-0.716^{* *}$ & 2.055 & -0.121 & $-0.127^{*}$ & \\
\hline Observations & 1250 & 1250 & 1239 & 1157 & 1212 & 976 & 1250 & 1236 & 1250 \\
\hline Countries & 25 & 25 & 25 & 24 & 24 & 18 & 25 & 25 & 25 \\
\hline F-statistic & 3.952 & 6.900 & 11.87 & 12.45 & 5.799 & 2.749 & 20.18 & 22.77 & 15.46 \\
\hline
\end{tabular}

Source: Authors' calculations.

Notes: Net inflows (in percent of trend GDP) for each country are instrumented using gross inflows to other EMs (in percent of trend GDP). Results are presented in terms of net outflows. The US policy rate is the effective federal funds rate except during the zero lower bound period where the implied policy rate from Wu and Xia (2015) is used. The estimations are done using fixed effects on a panel of EMs, excluding countries with pegged and freely falling exchange rates (Ilzetzki et al., 2019), during 2000Q1 to 2016Q4. Driscoll-Kraay standard errors are reported in parenthesis. ${ }^{* * *},{ }^{* *}$, and ${ }^{*}$ indicate statistical significance on 1, 5, and 10, percent level, respectively. 
Table 10: Dampening Effects of Capital Controls on GDP Growth

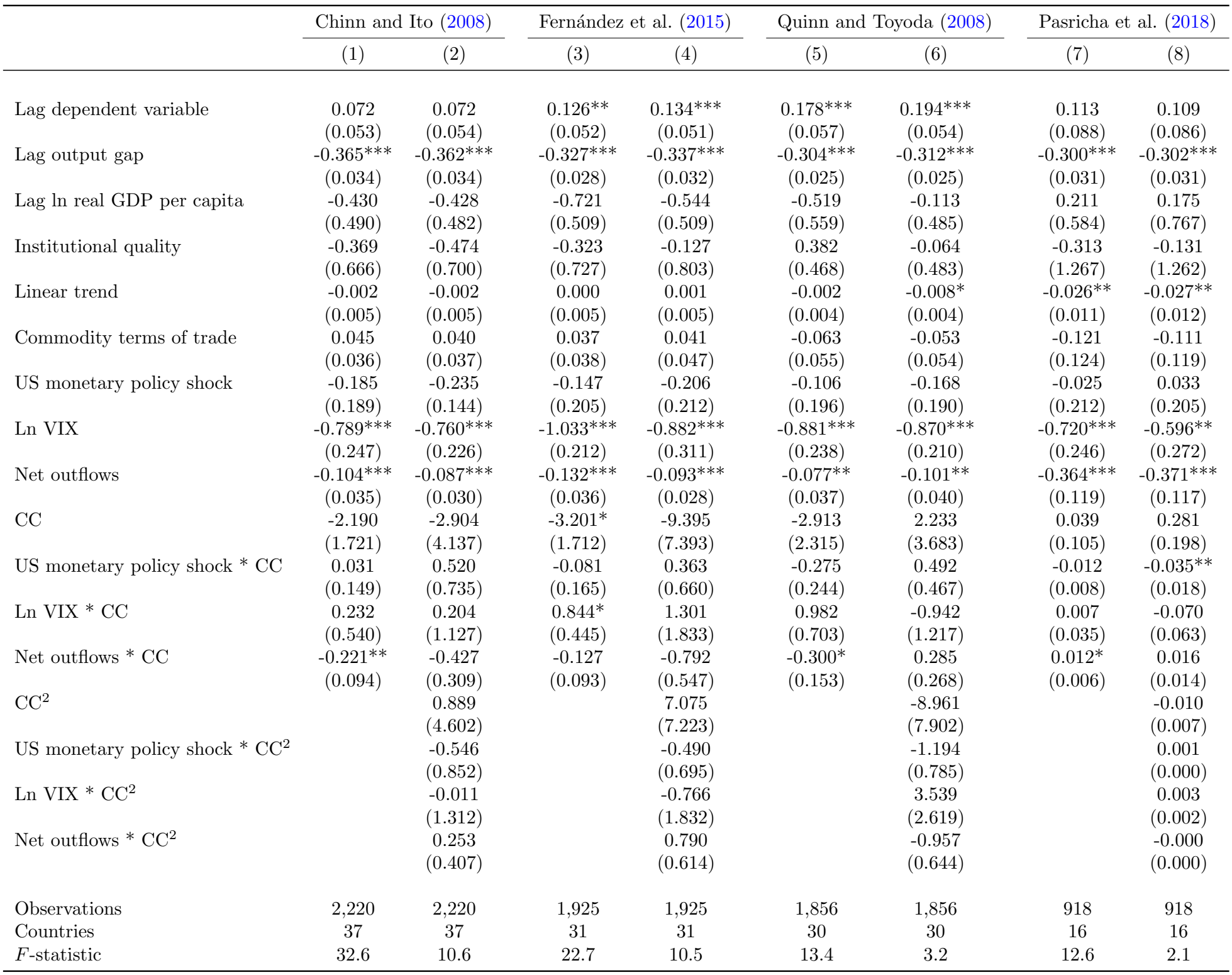

Source: Authors' calculations.

Notes: Net inflows (in percent of trend GDP) for each country are instrumented using gross inflows to other EMs (in percent of trend GDP).

Results are presented in terms of net outflows. The estimations are based on a sample of EM from 2000Q1 to 2016Q4. All specifications include country fixed effects. Driscoll-Kraay standard errors are reported in parentheses. ${ }^{* * *}$, $* *$, and $*$ indicate statistical significance at 1,5 , and 10 percent, respectively. 
Table 11: Dampening Effects of Inflow and Outflow Capital Controls on GDP Growth

\begin{tabular}{|c|c|c|c|c|c|c|c|c|}
\hline & \multicolumn{4}{|c|}{ Fernández et al. (2015) } & \multicolumn{4}{|c|}{ Pasricha et al. (2018) } \\
\hline & \multicolumn{2}{|c|}{$\mathrm{CC}$ on inflows } & \multicolumn{2}{|c|}{$\mathrm{CC}$ on outflows } & \multicolumn{2}{|c|}{$\mathrm{CC}$ on inflows } & \multicolumn{2}{|c|}{$\mathrm{CC}$ on outflows } \\
\hline & (1) & $(2)$ & $(3)$ & $(4)$ & $(5)$ & (6) & (7) & $(8)$ \\
\hline Lag dependent variable & $\begin{array}{c}0.124^{* *} \\
(0.053)\end{array}$ & $\begin{array}{c}0.125^{* *} \\
(0.051)\end{array}$ & $\begin{array}{c}0.127^{* *} \\
(0.051)\end{array}$ & $\begin{array}{c}0.125^{* *} \\
(0.055)\end{array}$ & $\begin{array}{c}0.112 \\
(0.091)\end{array}$ & $\begin{array}{c}0.105 \\
(0.093)\end{array}$ & $\begin{array}{c}0.092 \\
(0.096)\end{array}$ & $\begin{array}{c}0.095 \\
(0.093)\end{array}$ \\
\hline Lag output gap & $\begin{array}{c}-0.326^{* * *} \\
(0.028)\end{array}$ & $\begin{array}{c}-0.327^{* * *} \\
(0.029)\end{array}$ & $\begin{array}{c}-0.329^{* * *} \\
(0.028)\end{array}$ & $\begin{array}{c}-0.327^{* * *} \\
(0.032)\end{array}$ & $\begin{array}{c}-0.299^{* * *} \\
(0.034)\end{array}$ & $\begin{array}{c}-0.299^{* * *} \\
(0.032)\end{array}$ & $\begin{array}{c}-0.288^{* * *} \\
(0.039)\end{array}$ & $\begin{array}{c}-0.300 * * * \\
(0.037)\end{array}$ \\
\hline Lag ln real GDP per capita & $\begin{array}{l}-0.713 \\
(0.503)\end{array}$ & $\begin{array}{l}-0.685 \\
(0.525)\end{array}$ & $\begin{array}{c}-0.691 \\
(0.510)\end{array}$ & $\begin{array}{l}-0.587 \\
(0.520)\end{array}$ & $\begin{array}{c}0.254 \\
(0.636)\end{array}$ & $\begin{array}{c}0.344 \\
(0.664)\end{array}$ & $\begin{array}{l}-0.115 \\
(0.872)\end{array}$ & $\begin{array}{c}0.644 \\
(0.812)\end{array}$ \\
\hline Institutional quality & $\begin{array}{l}-0.221 \\
(0.739)\end{array}$ & $\begin{array}{l}-0.385 \\
(0.743)\end{array}$ & $\begin{array}{l}-0.393 \\
(0.727)\end{array}$ & $\begin{array}{c}0.513 \\
(0.869)\end{array}$ & $\begin{array}{c}-0.351 \\
(1.306)\end{array}$ & $\begin{array}{l}-0.543 \\
(1.333)\end{array}$ & $\begin{array}{c}0.257 \\
(1.363)\end{array}$ & $\begin{array}{c}0.033 \\
(1.501)\end{array}$ \\
\hline Linear trend & $\begin{array}{c}0.001 \\
(0.005)\end{array}$ & $\begin{array}{c}0.001 \\
(0.005)\end{array}$ & $\begin{array}{c}0.000 \\
(0.005)\end{array}$ & $\begin{array}{c}0.003 \\
(0.006)\end{array}$ & $\begin{array}{c}-0.022^{* *} \\
(0.010)\end{array}$ & $\begin{array}{c}-0.027^{* *} \\
(0.012)\end{array}$ & $\begin{array}{c}-0.033^{* *} \\
(0.013)\end{array}$ & $\begin{array}{c}-0.034^{* *} \\
(0.015)\end{array}$ \\
\hline Commodity terms of trade & $\begin{array}{c}0.034 \\
(0.038)\end{array}$ & $\begin{array}{c}0.033 \\
(0.041)\end{array}$ & $\begin{array}{c}0.039 \\
(0.038)\end{array}$ & $\begin{array}{c}0.071 \\
(0.058)\end{array}$ & $\begin{array}{c}-0.151 \\
(0.128)\end{array}$ & $\begin{array}{c}-0.109 \\
(0.129)\end{array}$ & $\begin{array}{c}-0.146 \\
(0.132)\end{array}$ & $\begin{array}{l}-0.155 \\
(0.135)\end{array}$ \\
\hline US monetary policy shock & $\begin{array}{l}-0.178 \\
(0.204)\end{array}$ & $\begin{array}{c}-0.152 \\
(0.181)\end{array}$ & $\begin{array}{l}-0.125 \\
(0.202)\end{array}$ & $\begin{array}{c}-0.244 \\
(0.220)\end{array}$ & $\begin{array}{l}-0.050 \\
(0.213)\end{array}$ & $\begin{array}{l}-0.003 \\
(0.217)\end{array}$ & $\begin{array}{c}0.049 \\
(0.244)\end{array}$ & $\begin{array}{c}0.129 \\
(0.253)\end{array}$ \\
\hline Ln VIX & $\begin{array}{c}-0.992^{\text {*** }} \\
(0.185)\end{array}$ & $\begin{array}{c}-0.895^{* * *} \\
(0.287)\end{array}$ & $\begin{array}{c}-1.039^{* * *} \\
(0.225)\end{array}$ & $\begin{array}{c}-0.872^{* * *} \\
(0.278)\end{array}$ & $\begin{array}{c}-0.705^{* * *} \\
(0.237)\end{array}$ & $\begin{array}{c}-0.641^{* *} \\
(0.251)\end{array}$ & $\begin{array}{c}-0.344 \\
(0.370)\end{array}$ & $\begin{array}{l}-0.368 \\
(0.374)\end{array}$ \\
\hline Net outflows & $\begin{array}{c}-0.127^{* * *} \\
(0.039)\end{array}$ & $\begin{array}{c}-0.124^{* * *} \\
(0.037)\end{array}$ & $\begin{array}{c}-0.140^{* * *} \\
(0.035)\end{array}$ & $\begin{array}{c}-0.103^{* * *} \\
(0.028)\end{array}$ & $\begin{array}{c}-0.344^{* * *} \\
(0.121)\end{array}$ & $\begin{array}{c}-0.367^{* * *} \\
(0.130)\end{array}$ & $\begin{array}{c}-0.537^{* * *} \\
(0.187)\end{array}$ & $\begin{array}{c}-0.513^{* * *} \\
(0.189)\end{array}$ \\
\hline $\mathrm{CC}$ & $\begin{array}{r}-3.267^{*} \\
(1.686)\end{array}$ & $\begin{array}{l}-2.548 \\
(6.667)\end{array}$ & $\begin{array}{l}-2.775^{*} \\
(1.548)\end{array}$ & $\begin{array}{c}-15.964^{*} \\
(8.493)\end{array}$ & $\begin{array}{c}0.100 \\
(0.139)\end{array}$ & $\begin{array}{l}-0.379 \\
(0.315)\end{array}$ & $\begin{array}{c}-0.703^{*} \\
(0.391)\end{array}$ & $\begin{array}{c}-0.633 \\
(0.591)\end{array}$ \\
\hline US monetary policy shock $*$ CC & $\begin{array}{l}-0.030 \\
(0.154)\end{array}$ & $\begin{array}{c}-0.359 \\
(0.717)\end{array}$ & $\begin{array}{l}-0.105 \\
(0.160)\end{array}$ & $\begin{array}{c}0.774 \\
(0.706)\end{array}$ & $\begin{array}{c}0.018 \\
(0.012)\end{array}$ & $\begin{array}{c}0.082^{* * *} \\
(0.027)\end{array}$ & $\begin{array}{c}0.043 \\
(0.036)\end{array}$ & $\begin{array}{c}0.076 \\
(0.058)\end{array}$ \\
\hline Ln $\mathrm{VIX} * \mathrm{CC}$ & $\begin{array}{l}0.852^{*} \\
(0.435)\end{array}$ & $\begin{array}{c}0.110 \\
(1.911)\end{array}$ & $\begin{array}{c}0.762^{*} \\
(0.419)\end{array}$ & $\begin{array}{c}3.029 \\
(1.923)\end{array}$ & $\begin{array}{c}-0.064 \\
(0.050)\end{array}$ & $\begin{array}{c}0.042 \\
(0.102)\end{array}$ & $\begin{array}{c}0.157 \\
(0.106)\end{array}$ & $\begin{array}{c}0.230 \\
(0.183)\end{array}$ \\
\hline Net outflows * CC & $\begin{array}{c}-0.152 \\
(0.101)\end{array}$ & $\begin{array}{c}-0.123 \\
(0.473)\end{array}$ & $\begin{array}{l}-0.104 \\
(0.084)\end{array}$ & $\begin{array}{c}-1.194^{* *} \\
(0.594)\end{array}$ & $\begin{array}{l}-0.012 \\
(0.008)\end{array}$ & $\begin{array}{c}-0.034^{* *} \\
(0.016)\end{array}$ & $\begin{array}{c}-0.078^{* *} \\
(0.038)\end{array}$ & $\begin{array}{l}-0.050 \\
(0.050)\end{array}$ \\
\hline $\mathrm{CC}^{2}$ & & $\begin{array}{l}-0.997 \\
(6.966)\end{array}$ & & $\begin{array}{c}14.307^{*} \\
(8.099)\end{array}$ & & $\begin{array}{l}-0.009 \\
(0.016)\end{array}$ & & $\begin{array}{c}-0.037 \\
(0.059)\end{array}$ \\
\hline US monetary policy shock $* \mathrm{CC}^{2}$ & & $\begin{array}{c}0.421 \\
(0.791)\end{array}$ & & $\begin{array}{l}-0.946 \\
(0.764)\end{array}$ & & $\begin{array}{c}0.003^{* * *} * \\
(0.001)\end{array}$ & & $\begin{array}{c}0.002 \\
(0.006)\end{array}$ \\
\hline Ln VIX $* \mathrm{CC}^{2}$ & & $\begin{array}{c}0.828 \\
(2.035)\end{array}$ & & $\begin{array}{c}-2.841 \\
(1.979)\end{array}$ & & $\begin{array}{c}0.001 \\
(0.006)\end{array}$ & & $\begin{array}{c}0.020 \\
(0.018)\end{array}$ \\
\hline Net outflows $* \mathrm{CC}^{2}$ & & $\begin{array}{l}-0.058 \\
(0.526)\end{array}$ & & $\begin{array}{c}-1.236^{*} \\
(0.631)\end{array}$ & & $\begin{array}{l}-0.000 \\
(0.001)\end{array}$ & & $\begin{array}{c}0.001 \\
(0.005)\end{array}$ \\
\hline Observations & 1,925 & 1,925 & 1,925 & 1,925 & 918 & 918 & 918 & 918 \\
\hline Countries & 31 & 31 & 31 & 31 & 16 & 16 & 16 & 16 \\
\hline$F$-statistic & 30.2 & 18.5 & 19.3 & 6.5 & 9.1 & 6.2 & 3.7 & 2.5 \\
\hline
\end{tabular}

Source: Authors' calculations.

Notes: Net inflows (in percent of trend GDP) for each country are instrumented using gross inflows to other EMs (in percent of trend GDP). Results are presented in terms of net outflows. The estimations are based on a sample of EM from 2000Q1 to 2016Q4. All specifications include country fixed effects. Driscoll-Kraay standard errors are reported in parentheses. ***, **, and * indicate statistical significance at 1,5 , and 10 percent, respectively. 
Table 12: Regressions of Domestic Policy Rates: Capital Controls

\begin{tabular}{|c|c|c|c|c|}
\hline & $\begin{array}{l}\text { Chinn and Ito } \\
\text { (2008) }\end{array}$ & $\begin{array}{l}\text { Fernández et } \\
\text { al. (2015) }\end{array}$ & $\begin{array}{l}\text { Quinn and } \\
\text { Toyoda } \\
(2008)\end{array}$ & $\begin{array}{l}\text { Pasricha et } \\
\text { al. (2018) }\end{array}$ \\
\hline & (1) & $(2)$ & $(3)$ & $(4)$ \\
\hline US policy rate & $\begin{array}{c}0.153^{* * *} \\
(0.050)\end{array}$ & $\begin{array}{l}0.110^{*} \\
(0.057)\end{array}$ & $\begin{array}{c}0.258^{* * *} \\
(0.051)\end{array}$ & $\begin{array}{c}0.336^{* * *} \\
(0.049)\end{array}$ \\
\hline Ln VIX & $\begin{array}{c}0.798^{* * *} \\
(0.266)\end{array}$ & $\begin{array}{l}-0.127 \\
(0.381)\end{array}$ & $\begin{array}{c}0.212 \\
(0.363)\end{array}$ & $\begin{array}{l}0.718^{*} \\
(0.370)\end{array}$ \\
\hline Net outflows & $\begin{array}{c}0.056 \\
(0.072)\end{array}$ & $\begin{array}{l}0.094^{*} \\
(0.055)\end{array}$ & $\begin{array}{c}0.185^{* *} \\
(0.075)\end{array}$ & $\begin{array}{c}0.249^{* *} \\
(0.109)\end{array}$ \\
\hline Expected inflation, next 12 months & $\begin{array}{c}1.077^{* * *} \\
(0.082)\end{array}$ & $\begin{array}{c}1.207^{* * *} * \\
(0.079)\end{array}$ & $\begin{array}{c}1.207^{* * *} * \\
(0.082)\end{array}$ & $\begin{array}{c}1.167^{* * *} \\
(0.102)\end{array}$ \\
\hline Output gap & $\begin{array}{l}0.115^{* *} \\
(0.057)\end{array}$ & $\begin{array}{l}0.106^{*} \\
(0.059)\end{array}$ & $\begin{array}{c}0.147^{* *} \\
(0.069)\end{array}$ & $\begin{array}{c}0.121 \\
(0.091)\end{array}$ \\
\hline Real credit growth & $\begin{array}{c}0.031^{* * *} \\
(0.011)\end{array}$ & $\begin{array}{c}0.044^{* * *} \\
(0.011)\end{array}$ & $\begin{array}{c}0.040^{* * *} \\
(0.014)\end{array}$ & $\begin{array}{c}0.055^{* * *} \\
(0.018)\end{array}$ \\
\hline Commodity terms of trade & $\begin{array}{l}-0.043 \\
(0.037)\end{array}$ & $\begin{array}{l}-0.062 \\
(0.039)\end{array}$ & $\begin{array}{l}-0.019 \\
(0.043)\end{array}$ & $\begin{array}{l}-0.040 \\
(0.059)\end{array}$ \\
\hline $\mathrm{CC}$ & $\begin{array}{c}7.983^{* * *} \\
(2.515)\end{array}$ & $\begin{array}{l}-1.504 \\
(3.278)\end{array}$ & $\begin{array}{l}4.462 \\
(5.664)\end{array}$ & $\begin{array}{c}0.062 \\
(0.146)\end{array}$ \\
\hline $\mathrm{CC} *$ US policy rate & $\begin{array}{c}0.279^{* * *} \\
(0.095)\end{array}$ & $\begin{array}{c}0.274^{* * *} \\
(0.083)\end{array}$ & $\begin{array}{l}-0.152 \\
(0.181)\end{array}$ & $\begin{array}{l}-0.019^{*} \\
(0.011)\end{array}$ \\
\hline $\mathrm{CC} * \operatorname{Ln} \mathrm{VIX}$ & $\begin{array}{l}-0.702 \\
(0.710)\end{array}$ & $\begin{array}{c}0.887 \\
(0.974)\end{array}$ & $\begin{array}{c}0.635 \\
(1.747)\end{array}$ & $\begin{array}{l}-0.042 \\
(0.044)\end{array}$ \\
\hline $\mathrm{CC} *$ Net outflows & $\begin{array}{c}0.404^{* * *} \\
(0.145)\end{array}$ & $\begin{array}{c}0.415^{* * *} \\
(0.136)\end{array}$ & $\begin{array}{c}0.420 \\
(0.341)\end{array}$ & $\begin{array}{l}-0.063 \\
(0.068)\end{array}$ \\
\hline Observations & 1250 & 1250 & 1171 & 806 \\
\hline Countries & 25 & 25 & 23 & 15 \\
\hline F-statistic & 15.07 & 27.80 & 8.975 & 2.818 \\
\hline
\end{tabular}

Source: Authors' calculations.

Notes: Net inflows (in percent of trend GDP) for each country are instrumented using gross inflows to other EMs (in percent of trend GDP). Results are presented in terms of net outflows. The US policy rate is the effective federal funds rate except during the zero lower bound period where the implied policy rate from $\mathrm{Wu}$ and Xia (2015) is used. The estimations are done using fixed effects on a panel of EMs, excluding countries with pegged and freely falling exchange rates (Ilzetzki et al., 2019), during 2000Q1 to 2016Q4. Driscoll-Kraay standard errors are reported in parenthesis. ***,**, and $*$ indicate statistical significance on 1,5 , and 10 , percent level, respectively. 
Table 13: Regressions of Domestic Policy Rates: Capital Controls on Inflows and Outflows

\begin{tabular}{|c|c|c|c|c|}
\hline & \multicolumn{2}{|c|}{ Fernández et al. (2015) } & \multicolumn{2}{|c|}{ Pasricha et al. (2018) } \\
\hline & $\mathrm{CC}$ on inflows & CC on outflows & CC on inflows & CC on outflows \\
\hline & $(1)$ & $(2)$ & $(3)$ & $(4)$ \\
\hline US policy rate & $\begin{array}{c}0.163^{* * *} \\
(0.047)\end{array}$ & $\begin{array}{c}0.101 \\
(0.064)\end{array}$ & $\begin{array}{c}0.336^{* * *} \\
(0.044)\end{array}$ & $\begin{array}{c}0.288^{* * *} \\
(0.063)\end{array}$ \\
\hline Ln VIX & $\begin{array}{c}0.183 \\
(0.309)\end{array}$ & $\begin{array}{l}-0.242 \\
(0.384)\end{array}$ & $\begin{array}{c}0.788^{* *} \\
(0.353)\end{array}$ & $\begin{array}{c}0.574 \\
(0.451)\end{array}$ \\
\hline Net outflows & $\begin{array}{c}0.130^{* *} \\
(0.058)\end{array}$ & $\begin{array}{l}0.095^{*} \\
(0.056)\end{array}$ & $\begin{array}{c}0.193^{* *} \\
(0.097)\end{array}$ & $\begin{array}{c}0.323^{* *} \\
(0.157)\end{array}$ \\
\hline Expected inflation, next 12 months & $\begin{array}{c}1.205^{* * *} \\
(0.078)\end{array}$ & $\begin{array}{c}1.213^{* * *} \\
(0.079)\end{array}$ & $\begin{array}{c}1.205^{* * *} \\
(0.097)\end{array}$ & $\begin{array}{c}1.174^{* * *} \\
(0.099)\end{array}$ \\
\hline Output gap & $\begin{array}{l}0.109^{*} \\
(0.060)\end{array}$ & $\begin{array}{c}0.110^{*} \\
(0.060)\end{array}$ & $\begin{array}{c}0.108 \\
(0.093)\end{array}$ & $\begin{array}{c}0.127 \\
(0.087)\end{array}$ \\
\hline Real credit growth & $\begin{array}{c}0.045^{* * *} \\
(0.012)\end{array}$ & $\begin{array}{c}0.044^{* * *} \\
(0.011)\end{array}$ & $\begin{array}{c}0.052^{* * *} \\
(0.016)\end{array}$ & $\begin{array}{c}0.063^{* * *} \\
(0.020)\end{array}$ \\
\hline Commodity terms of trade & $\begin{array}{c}-0.069^{*} \\
(0.038)\end{array}$ & $\begin{array}{l}-0.062 \\
(0.039)\end{array}$ & $\begin{array}{l}-0.029 \\
(0.054)\end{array}$ & $\begin{array}{l}-0.030 \\
(0.052)\end{array}$ \\
\hline $\mathrm{CC}$ & $\begin{array}{c}0.024 \\
(3.011)\end{array}$ & $\begin{array}{l}-2.201 \\
(2.912)\end{array}$ & $\begin{array}{c}-0.746^{* *} \\
(0.336)\end{array}$ & $\begin{array}{c}0.359 \\
(0.396)\end{array}$ \\
\hline $\mathrm{CC} *$ US policy rate & $\begin{array}{c}0.219^{* * *} \\
(0.076)\end{array}$ & $\begin{array}{c}0.258^{* * *} \\
(0.085)\end{array}$ & $\begin{array}{c}0.034^{* *} \\
(0.017)\end{array}$ & $\begin{array}{c}0.035^{* * *} \\
(0.012)\end{array}$ \\
\hline $\mathrm{CC} *$ Ln VIX & $\begin{array}{c}0.421 \\
(0.880)\end{array}$ & $\begin{array}{c}0.985 \\
(0.896)\end{array}$ & $\begin{array}{c}0.248^{* *} \\
(0.101)\end{array}$ & $\begin{array}{c}-0.047 \\
(0.110)\end{array}$ \\
\hline $\mathrm{CC} *$ Net outflows & $\begin{array}{c}0.398^{* * *} \\
(0.147)\end{array}$ & $\begin{array}{c}0.384^{* * * *} \\
(0.122)\end{array}$ & $\begin{array}{c}-0.058^{* *} \\
(0.028)\end{array}$ & $\begin{array}{c}0.016 \\
(0.030)\end{array}$ \\
\hline Observations & 1250 & 1250 & 806 & 806 \\
\hline Country FE & Yes & Yes & Yes & Yes \\
\hline F-statistic & 26.95 & 30 & 8.712 & 5.566 \\
\hline
\end{tabular}

Source: Authors' calculations.

Notes: Net inflows (in percent of trend GDP) for each country are instrumented using gross inflows to other EMs (in percent of trend GDP). Results are presented in terms of net outflows. The US policy rate is the effective federal funds rate except during the zero lower bound period where the implied policy rate from $\mathrm{Wu}$ and Xia (2015) is used. The estimations are done using fixed effects on a panel of EMs, excluding countries with pegged and freely falling exchange rates (Ilzetzki et al., 2019), during 2000Q1 to 2016Q4. Driscoll-Kraay standard errors are reported in parenthesis. $* * * * *$, and $*$ indicate statistical significance on 1,5 , and 10 , percent level, respectively. 


\section{Appendix A. Data}

Table A.1 lists the data sources used in the analysis. The country coverage is reported in Table A.2. The sample consists of $38 \mathrm{EMs}$, based on the April 2020 World Economic Outlook classification, from the first quarter of 2000 to the last quarter of 2016. The criteria used for the country and period selection are: (i) a population larger than one million, (ii) at least 10 years of GDP data, (iii) at least 5 years of data for net capital inflows, (iv) data on macroprudential regulation from the iMaPP databases of Alam et al. (2019).

Table A.1: Data Sources

\begin{tabular}{|c|c|}
\hline Capital Flow Measures & Fernandez and others (2016) \\
\hline Commodity terms of trade & Gruss and Kebhaj (2019) \\
\hline Exchange rate regime & Ilzetzki and others (2019) \\
\hline Expected inflation & Consensus forecast, Haver Analytics, IMF staff calculations \\
\hline Gross capital inflows & IMF, Balance of Payment Statistics \\
\hline Gross capital outflows without FX reserves & IMF, Balance of Payment Statistics \\
\hline $\begin{array}{l}\text { Gross public debt in foreign currency to gross } \\
\text { public debt }\end{array}$ & IMF, World Economic Outlook \\
\hline Gross public debt to GDP & IMF, World Economic Outlook \\
\hline Inflation & Haver Analytics \\
\hline Inflation expectation anchoring index & Bems and others (2018) \\
\hline Institutional quality & Worldwide Governance Indicators \\
\hline Official reserves & IMF, Balance of Payment Statistics \\
\hline Macroprudential regulation & iMaPP dataset, Alam and others (2019) \\
\hline Net capital inflows & IMF, Balance of Payment Statistics \\
\hline Nominal effective exchange rate & IMF staff calculations \\
\hline Nominal gross domestic product & Haver Analytics \\
\hline Policy rates & $\begin{array}{l}\text { Bank of International Settlement; Haver Analytics; and IMF, } \\
\text { International Financial Statistics }\end{array}$ \\
\hline Population & IMF, World Economic Outlook \\
\hline Real credit & $\begin{array}{l}\text { Bank of International Settlement; Haver Analytics; and IMF, } \\
\text { International Financial Statistics }\end{array}$ \\
\hline Real effective exchange rate & IMF staff calculations \\
\hline Real GDP & Haver Analytics \\
\hline Real house prices & IMF, Global House Watch \\
\hline Real investment & IMF, World Economic Outlook \\
\hline Real private consumption & IMF, World Economic Outlook \\
\hline Reserve assets & IMF, Balance of Payment Statistics \\
\hline VIX & Haver Analytics \\
\hline
\end{tabular}

Source: IMF staff compilation.

In some instances, the analysis differentiates countries depending on whether the exchange rate is fixed or flexible using the coarse classification in Ilzetzki et al. (2019). Flexible exchange rate regimes include bands, crawls, and managed floats (categories 2, 3, and 4). Fixed exchange rate regimes include hard pegs, currency board arrangements, horizontal bands, and de facto pegs (category 1). Freely falling exchange rate regimes are excluded from the analysis (category 5).

Data on macroprudential measures are from the IMF's integrated Macroprudential Policy (iMaPP) that provides information on 17 macroprudential tools (Alam et al., 2019). These measures are grouped into an overall index and in five subcategories targeting bank capital, credit demand, credit supply, foreign exchange positions, and liquidity. The mapping between the iMaPP variables and the five categories is shown in Table A.3. The stringency of macroprudential regulation is measured by cumulating the net tightening actions for 
Table A.2: Country Coverage

\begin{tabular}{lll}
\hline Country & & \\
\hline Albania & El Salvador & Paraguay \\
Argentina & Georgia & Peru \\
Belarus & Hungary & Philippines \\
Bosnia and Herzegovina & India & Poland \\
Brazil & Indonesia & Romania \\
Bulgaria & Jamaica & Russia \\
Chile & Jordan & Serbia \\
China & Kazakhstan & South Africa \\
Colombia & Malaysia & Thailand \\
Costa Rica & Mexico & Turkey \\
Croatia & Morocco & Ukraine \\
Dominican Republic & Northern Macedonia & Uruguay \\
Ecuador & Pakistan & \\
\hline
\end{tabular}

Source: IMF staff compilation.

each country since 1990, the first year in the iMaPP database, as illustrated in panel 2 of Figure $2 .{ }^{31}$

Table A.3: Categories of Macroprudential Measures

\begin{tabular}{lll}
\hline Category & Measure & Notes \\
\hline Capital & $\begin{array}{l}\text { Capital Requirements (capital) } \\
\text { Leverage Limits (LVR) } \\
\text { Loan Loss Requirements (LLP) }\end{array}$ & Including risk weights \\
& $\begin{array}{l}\text { Countercyclical Capital Buffer (CCB) } \\
\text { Capital Conservation Buffer (Conservation) }\end{array}$ & $\begin{array}{l}\text { Including dynamic and sector-specific provi- } \\
\text { sioning (e.g. housing) }\end{array}$ \\
& Measures targeted at SIFIs (SIFI) & Including capital and liquidity surcharges \\
\hline Credit Demand & $\begin{array}{l}\text { Loan-To-Value ratio (LTV) } \\
\text { Debt-Service-to-Income ratio (DSTI) } \\
\text { Tax on Transactions (tax) }\end{array}$ & Mostly targeted at housing loans \\
& $\begin{array}{l}\text { Limits on Credit Growth (LCG) } \\
\text { Lredit Supply }\end{array}$ & Including stamp duties and capital gain taxes \\
\hline FX Exposure & $\begin{array}{l}\text { Limit on Foreign Currency (LFC) } \\
\text { Limit on gross open FX positions (LFX) }\end{array}$ & $\begin{array}{l}\text { Including penalties for values } \\
\text { Tailored LCG conditional on loan and bank } \\
\text { characteristics, or other factors }\end{array}$ \\
\hline Reserve Requirements on FC assets (RR_FCD) & $\begin{array}{l}\text { Limits on foreign currency lending } \\
\text { Including currency mismatch regulations }\end{array}$ \\
\hline Liquidity & $\begin{array}{l}\text { Reserve Requirements (RR_dom) } \\
\text { Liquidity Measures (liquidity) }\end{array}$ & $\begin{array}{l}\text { On domestic currency assets } \\
\text { Including liquidity coverage ratios, liquid asset } \\
\text { ratios, net stable funding ratios, core funding } \\
\text { ratios, and ext. debt restrictions } \\
\text { Including penalties for high values }\end{array}$ \\
\hline
\end{tabular}

Source: iMaPP dataset.

Notes: The name of the variable in the iMaPP dataset is reported in parentheses.

\footnotetext{
${ }^{31}$ In the econometric analysis, the cumulated macroprudential indexes are rescaled across all countries so that values are always positive. This is because the regression framework includes squared values of these indexes.
} 


\section{References}

Acharya, Viral, Katharina Bergant, Matteo Crosignani, Fergal McCann, and Tim Eisert (2020). "The Anatomy of the Transmission of Macroprudential Policy". Working paper.

Agénor, Pierre-Richard, Leonardo Gambacorta, Enisse Kharroubi, and Luiz A. Pereira da Silva (2018). "The Effects of Prudential Regulation, Financial Development, and Financial Openness on Economic Growth". BIS Working Paper 752.

Ahnert, Toni, Kristin J. Forbes, and Dennis Reinhardt (2018). "Macroprudential FX Regulations: Shifting the Snowbanks of FX Vulnerability?" NBER Working Paper 25083.

Aiyar, Shekhar, Charles W. Calomiris, and Tomasz Wieladek (2014). "Does Macro-pru Leak? Evidence from a UK Policy Experiment". Journal of Money, Credit and Banking 46.1, pp. 368-82.

- (2016). "How does credit supply respond to monetary policy and bank minimum capital requirements?" European Economic Review 82, pp. 142-165.

Aizenman, Joshua, Menzie D. Chinn, and Hiro Ito (2016). "Monetary Policy Spillovers and the Trilemma in the New Normal: Periphery Country Sensitivity to Core Country Conditions". Journal of International Money and Finance 68, pp. 298-330.

- (2017). "Financial Spillovers and Macroprudential Policies". NBER Working Paper 24105.

Akinci, Ozge and Jane Olmstead-Rumsey (2018). "How Effective are Macroprudential Policies? An Empirical Investigation". Journal of Financial Intermediation 33, pp. 33-57.

Alam, Zohair, Adrian Alter, Jesse Eiseman, Gaston Gelos, Heedon Kang, Machiko Narita, Erlend Nier, and Naixi Wang (2019). "Digging Deeper-Evidence on the Effects of Macroprudential Policies from a New Database". IMF Working Paper 19/66.

Aoki, Kosuke, Gianluca Benigno, and Nobuhiro Kiyotaki (2019). "Monetary and Financial Policies in Emerging Markets". Working Paper 19.

Auer, Raphael A. and Steven Ongena (2019). "The Countercyclical Capital Buffer and the Composition of Bank Lending". CESifo Working Paper Series 7815.

Bems, Rudolfs, Francesca G. Caselli, Francesco Grigoli, Bertrand Gruss, and Weicheng Lian (2018). "Expectations' Anchoring and Inflation Persistence". IMF Working Paper 18/280.

Bengui, Julien and Javier Bianchi (2018). "Macroprudential policy with leakages". 25048.

Bhattarai, Saroj, Arpita Chatterjee, and Woong Yong Park (2020). "Global Spillover Effect of US Uncertainty". Journal of Monetary Economics forthcoming.

Blanchard, Olivier, Jonathan D. Ostry, Atish Ghosh, and Marcos Chamon (2017). "Are Capital Inflows Expansionary or Contractionary? Theory, Policy Implications, and Some Evidence". IMF Economic Review 65.3, pp. 563-85.

Boar, Codruta, Leonardo Gambacorta, Giovanni Lombardo, and Luiz A. Pereira da Silva (2017). "What are the effects of macroprudential policies on macroeconomic performance?" BIS Quarterly Review September September, pp. 71-99.

Braggion, Fabio, Alberto Manconi, and Haikun Zhu (2018). "Can technology undermine macroprudential regulation? Evidence from peer-to-peer credit in China". CEPR Discussion Paper DP12668.

Brando-Marques, Luis, Gaston Gelos, Machiko Narita, and Erlend Nier (2020). "Leaning Against the Wind: a Cost Benefit Analysis for an Integrated Policy Framework". IMF Working Paper. 
Bräuning, Falk and Victoria Ivashina (2020). "Monetary Policy and Global Banking". Journal of Finance forthcoming.

Canova, Fabio (2005). "The Transmission of US Shocks to Latin America". Journal of Applied Econometrics 20.2, pp. 229-251.

Cavallino, Paolo and Damiano Sandri (2020). "The Open-Economy ELB: Contractionary Monetary Easing and the Trilemma". CEPR Discussion Paper 14683.

Cerutti, Eugenio, Stijn Claessens, and Luc Laeven (2017). "The use and effectiveness of macroprudential policies: New evidence". Journal of Financial Stability 28, pp. 203-224.

Cerutti, Eugenio, Jihad Dagher, and Giovanni Dell'ariccia (2015). "Housing Finance and Real-Estate Booms; A Cross-Country Perspective". IMF Staff Discussion Notes 15/12.

Chinn, Menzie D. and Hiro Ito (2008). "A new measure of financial openness". Journal of comparative policy analysis 10.3 , pp. 309-322.

Choi, Woon Gyu, Taesu Kang, Geun-Young Kim, and Byongju Lee (2017). "Divergent emerging market economy responses to global and domestic monetary policy shocks". ADB Economics Working Paper 532.

Cizel, Janko, Jon Frost, Aerdt Houben, and Peter Wierts (2019). "Effective Macroprudential Policy: CrossSector Substitution from Price and Quantity Measures". Journal of Money, Credit and Banking 51.5, pp. 1209-1235.

Claessens, Stijn, Swati R Ghosh, and Roxana Mihet (2013). "Macroprudential policies to mitigate financial system vulnerabilities". Journal of International Money and Finance 39, pp. 153-185.

Crowe, Christopher, Giovanni Dell'Ariccia, Deniz Igan, and Pau Rabanal (2013). "How to deal with real estate booms: Lessons from country experiences". Journal of Financial Stability 9.3, pp. 300-319.

Dassatti, Cecilia Camors, José-Luis Peydró, and Francesc Rodriguez-Tous (2019). "Macroprudential and monetary policy: loan-level evidence from reserve requirements". Working Paper.

Dedola, Luca, Giulia Rivolta, and Livio Stracca (2017). "If the Fed sneezes, who catches a cold?" Journal of International Economics 108, pp. 23-41.

Dell'Ariccia, Giovanni, Deniz Igan, Luc Laeven, and Hui Tong (2012). "Policies for Macrofinancial Stability: How to Deal with Credit Booms". IMF Staff Discussion Note 12.06.

Driscoll, John C and Aart C. Kraay (1998). "Consistent covariance matrix estimation with spatially dependent panel data". Review of economics and statistics 80.4, pp. 549-560.

Egorov, Konstantin and Dmitry Mukhin (2019). "Optimal monetary policy under dollar pricing". Meeting Papers 1510, Society for Economic Dynamics.

Eickmeier, Sandra, Benedikt Kolb, and Esteban Prieto (2018). "Macroeconomic effects of bank capital regulation". Deutsche Bundesbank Discussion Paper 44/2018.

Erten, Bilge, Anton Korinek, and José Antonio Ocampo (2019). "Capital Controls: Theory and Evidence". NBER Working Paper No. $2644 \%$.

Erten, Bilge and José Antonio Ocampo (2017). "Macroeconomic effects of capital account regulations". IMF Economic Review 65.2, pp. 193-240.

Farhi, Emmanuel and Iván Werning (2016). "A theory of macroprudential policies in the presence of nominal rigidities". Econometrica 84.5, pp. 1645-1704.

Fendoğlu, Salih (2017). "Credit cycles and capital flows: Effectiveness of the macroprudential policy framework in emerging market economies". Journal of Banking \& Finance 79, pp. 110-128. 
Fernández, Andrés, Michael W. Klein, Alessandro Rebucci, Martin Schindler, and Martin Uribe (2016). "Capital control measures: A new dataset". IMF Economic Review 64.3, pp. 548-574.

Fernández, Andrés, Alessandro Rebucci, and Martín Uribe (2015). "Are capital controls countercyclical?" Journal of Monetary Economics 76, pp. 1-14.

Fleming, J. Marcus (1962). "Domestic financial policies under fixed and under floating exchange rates". IMF Staff Papers 9.3, pp. 369-380.

Forbes, Kristin J. (2018). "Macroprudential policy after the crisis: Forging a Thor's hammer for financial stability in Iceland". Report prepared for the Task Force to review monetary policy in Iceland.

Forbes, Kristin, Marcel Fratzscher, Thomas Kostka, and Roland Straub (2016). "Bubble thy neighbour: Portfolio effects and externalities from capital controls". Journal of International Economics 99, pp. 85104.

Forbes, Kristin, Marcel Fratzscher, and Roland Straub (2015). "Capital-flow management measures: What are they good for?" Journal of International Economics 96, S76-S97.

Frost, Jon, Hiro Ito, and René van Stralen (2020). "The effectiveness of macroprudential policies and capital controls against volatile capital inflows". BIS Working Papers No $86 \%$

Georgiadis, Georgios (2016). "Determinants of global spillovers from US monetary policy". Journal of International Money and Finance 67, pp. 41-61.

Giordani, Paolo E, Michele Ruta, Hans Weisfeld, and Ling Zhu (2017). "Capital flow deflection". Journal of International Economics 105, pp. 102-118.

Gopinath, Gita, Emine Boz, Camila Casas, Federico J Déz, Pierre-Olivier Gourinchas, and Mikkel PlagborgMøller (2020). "Dominant currency paradigm".

Han, Xuehui and Shang-Jin Wei (2018). "International transmissions of monetary shocks: Between a trilemma and a dilemma". Journal of International Economics 110, pp. 205-219.

Houston, Joel F, Chen Lin, and Yue Ma (2012). "Regulatory arbitrage and international bank flows". The Journal of Finance 67.5, pp. 1845-1895.

Iacoviello, Matteo and Gaston Navarro (2019). "Foreign effects of higher US interest rates". Journal of International Money and Finance 95, pp. 232-250.

Igan, Deniz and Heedon Kang (2011). "Do loan-to-value and debt-to-income limits work? Evidence from Korea". IMF Working Papers, pp. 1-34.

Ilzetzki, Ethan, Carmen M. Reinhart, and Kenneth S. Rogoff (2019). "Exchange arrangements entering the twenty-first century: Which anchor will hold?" The Quarterly Journal of Economics 134.2, pp. 599-646.

Im, Kyung So, M Hashem Pesaran, and Yongcheol Shin (2003). "Testing for unit roots in heterogeneous panels". Journal of Econometrics 115.1, pp. 53-74.

Jiménez, Gabriel, Steven Ongena, José-Luis Peydró, and Jesús Saurina (2017). "Macroprudential policy, countercyclical bank capital buffers, and credit supply: evidence from the Spanish dynamic provisioning experiments". Journal of Political Economy 125.6, pp. 2126-2177.

Kalemli-Özcan, Sebnem (2019). "US monetary policy and international risk spillovers". NBER Working Paper 26297.

Kao, Chihwa (1999). "Spurious regression and residual-based tests for cointegration in panel data". Journal of econometrics 90.1 , pp. 1-44.

Kim, Soyoung and Aaron Mehrotra (2018). "Effects of Monetary and Macroprudential Policies-Evidence from Four Inflation Targeting Economies". Journal of Money, Credit and Banking 50.5, pp. 967-992. 
Klein, Michael W (2012). "Capital controls: gates versus walls". Brookings Papers on Economic Activity, pp. 349-368.

Kuttner, Kenneth N and Ilhyock Shim (2016). "Can non-interest rate policies stabilize housing markets? Evidence from a panel of 57 economies". Journal of Financial Stability 26, pp. 31-44.

Lambert, Frederic J., Julio Ramos-Tallada, and Cyril Rebillard (2011). "Capital controls and spillover effects: evidence from Latin-American countries".

Lane, Philip R. and Gian Maria Milesi-Ferretti (2018). "The external wealth of nations revisited: international financial integration in the aftermath of the global financial crisis". IMF Economic Review 66.1, pp. 189222.

Levin, Andrew, Chien-Fu Lin, and Chia-Shang James Chu (2002). "Unit root tests in panel data: asymptotic and finite-sample properties". Journal of econometrics 108.1, pp. 1-24.

Maćkowiak, Bartosz (2007). "External shocks, US monetary policy and macroeconomic fluctuations in emerging markets". Journal of monetary economics 54.8, pp. 2512-2520.

McCann, Fergal and Conor O'Toole (2019). "Cross-Border Macroprudential Policy Spillovers and Bank Risk-Taking". International Journal of Central Banking 15.4, pp. 267-311.

Mundell, Robert A. (1963). "Capital mobility and stabilization policy under fixed and flexible exchange rates". Canadian Journal of Economics and Political Science 29.4, pp. 475-485.

Neanidis, Kyriakos C. (2019). "Volatile capital flows and economic growth: The role of banking supervision". Journal of Financial Stability 40, pp. 77-93.

Obstfeld, Maurice (2015). "Trilemmas and Tradeoffs: Living with Financial Globalization". Global Liquidity Spillovers to Emerging Markets and Policy Responses. Ed. by Claudio Raddatz, Diego Saravia, and Jaume Ventura. Central Bank of Chile.

Obstfeld, Maurice, Jonathan D. Ostry, and Mahvash S. Qureshi (2019). "A tie that binds: Revisiting the trilemma in emerging market economies". Review of Economics and Statistics 101.2, pp. 279-293.

Obstfeld, Maurice, Jay C. Shambaugh, and Alan M. Taylor (2005). "The trilemma in history: tradeoffs among exchange rates, monetary policies, and capital mobility". Review of Economics and Statistics 87.3, pp. $423-438$.

Ongena, Steven, Alexander Popov, and Gregory F Udell (2013). "When the cat's away the mice will play": Does regulation at home affect bank risk-taking abroad?" Journal of Financial Economics 108.3, pp. 727750 .

Ostry, Jonathan D., Atish R. Ghosh, Marcos Chamon, and Mahvash S. Qureshi (2012). "Tools for managing financial-stability risks from capital inflows". Journal of International Economics 88.2, pp. 407-421.

Ottonello, Pablo (2013). "Optimal exchange rate policy under collateral constraints and wage rigidity". Columbia University Department of Economics Discussion Papers 1213-25.

Pasricha, Gurnain K., Matteo Falagiarda, Martin Bijsterbosch, and Joshua Aizenman (2018). "Domestic and multilateral effects of capital controls in emerging markets". Journal of International Economics 115, pp. 48-58.

Quinn, Dennis P. and A. Maria Toyoda (2008). "Does capital account liberalization lead to growth?" The Review of Financial Studies 21.3, pp. 1403-1449.

Rebucci, Alessandro and Chang Ma (2019). "Capital Controls: A Survey of the New Literature". NBER Working Paper No. 26558. 
Reinhardt, Dennis and Rhiannon Sowerbutts (2015). "Regulatory arbitrage in action: evidence from banking flows and macroprudential policy".

Rey, Hélène (2015). "Dilemma not trilemma: the global financial cycle and monetary policy independence". NBER Working Paper 10591.

- (2016). "International channels of transmission of monetary policy and the Mundellian trilemma". IMF Economic Review 64.1, pp. 6-35.

Richter, Björn, Moritz Schularick, and Ilhyock Shim (2019). "The Cost of Macroprudential Policy". Journal of International Economics 118.2, pp. 263-82.

Saurina, Jesús (2009). "Dynamic provisioning: the experience of Spain". Crisis Response Note 7.

Shambaugh, Jay C (2004). "The effect of fixed exchange rates on monetary policy". The Quarterly Journal of Economics 119.1, pp. 301-352.

Tillmann, Peter (2015). "Estimating the effects of macroprudential policy shocks: A Qual VAR approach". Economics Letters 135, pp. 1-4.

Vicondoa, Alejandro (2019). "Monetary news in the United States and business cycles in emerging economies". Journal of International Economics 117, pp. 79-90.

Westerlund, Joakim (2007). "Testing for error correction in panel data". Oxford Bulletin of Economics and statistics 69.6, pp. 709-748.

Wong, Eric, Tom Fong, Kafai Li, and Henry Choi (2011). "Loan-to-Value Ratio as a Macro-Prudential Tool Hong Kong's Experience and Cross-Country Evidence". Hong Kong Monetary Authority Working Paper 1101.

Zeev, Nadav Ben (2017). "Capital controls as shock absorbers". Journal of International Economics 109, pp. $43-67$. 